\title{
Spending Multipliers with Distortionary Taxes: Does the Level of Public Debt Matter?*
}

\author{
Rym Aloui ${ }^{\dagger} \quad$ Aurélien Eyquem ${ }^{\ddagger}$
}

March 7, 2019

\begin{abstract}
We investigate the link between the size of government indebtedness and the effectiveness of government spending shocks in normal times and at the Zero Lower Bound (ZLB). We develop a New Keynesian model with capital, distortionary taxes and public debt in which the ZLB constraint on the nominal interest rate may be binding. In normal times, high steady-state levels of government debt to GDP lead to reduced output multipliers. After a negative capital quality shock that pushes the economy at the ZLB however, high steadystate debt levels produce larger output multipliers. Our results rely on the fact that fiscal policy becomes self-financing at the ZLB, and that distortionary taxes rise (respectively fall) after a spending shock at the steady state (resp. ZLB). Our results have non-trivial consequences on the design of optimized spending policies in the event of large economic downturns.
\end{abstract}

Keywords: Zero Lower Bound, Fiscal Policy, Distortionary Taxes, Public Debt.

JEL Classification: E62, E32.

\section{Introduction}

The massive rise in government debt levels and sovereign spreads that followed the 2008 Great Recession and the 2011 recession in countries of peripheral Europe raises the question of whether the level of public debt affects the effectiveness of government spending shocks. In other words, do high levels of sovereign debt undermine the ability of governments to make use of government spending to stabilize the economy? Conventional wisdom suggests that countries with high levels of public debt have less room for fiscal stimulation than countries with low levels of public debt in the event of an economic crisis, and would therefore advocate for low debt levels on average.

We investigate this question in a standard New-Keynesian model with capital accumulation where fiscal solvency is achieved through distortionary taxes on either labor or capital income. In the

\footnotetext{
${ }^{*}$ We would like to thank Julien Albertini, Hafedh Bouakez, Thomas Brand and participants of the T2M Lisbon and SCE New York conferences for thoughtful comments. Aurélien Eyquem gratefully acknowledges financial support of the ANR program entitled ANR-15-CE33-0001-02 FIRE.

${ }^{\dagger}$ Univ Lyon, Université Lumière Lyon 2, GATE UMR 5824, F-69130 Ecully, France. aloui@gate.cnrs.fr.

${ }^{\ddagger}$ Univ Lyon, Université Lumière Lyon 2, GATE UMR 5824, F-69130 Ecully, France; Institut Universitaire de France. aurelien.eyquem@univ-lyon2.fr.
} 


\title{
Spending Multipliers with Distortionary Taxes: Does the Level of Public Debt Matter?
}

\author{
March 7, 2019
}

\begin{abstract}
We investigate the link between the size of government indebtedness and the effectiveness of government spending shocks in normal times and at the Zero Lower Bound (ZLB). We develop a New Keynesian model with capital, distortionary taxes and public debt in which the ZLB constraint on the nominal interest rate may be binding. In normal times, high steady-state levels of government debt to GDP lead to reduced output multipliers. After a negative capital quality shock that pushes the economy at the ZLB however, high steadystate debt levels produce larger output multipliers. Our results rely on the fact that fiscal policy becomes self-financing at the ZLB, and that distortionary taxes rise (respectively fall) after a spending shock at the steady state (resp. ZLB). Our results have non-trivial consequences on the design of optimized spending policies in the event of large economic downturns.
\end{abstract}

Keywords: Zero Lower Bound, Fiscal Policy, Distortionary Taxes, Public Debt.

JEL Classification: E62, E32.

\section{Introduction}

The massive rise in government debt levels and sovereign spreads that followed the 2008 Great Recession and the 2011 recession in countries of peripheral Europe raises the question of whether the level of public debt affects the effectiveness of government spending shocks. In other words, do high levels of sovereign debt undermine the ability of governments to make use of government spending to stabilize the economy? Conventional wisdom suggests that countries with high levels of public debt have less room for fiscal stimulation than countries with low levels of public debt in the event of an economic crisis, and would therefore advocate for low debt levels on average.

We investigate this question in a standard New-Keynesian model with capital accumulation where fiscal solvency is achieved through distortionary taxes on either labor or capital income. In the data, countries with higher levels of debt also feature higher levels of tax rates (see Appendix A). Because debt is high, they potentially face larger costs of debt rollover, and because taxes are high, they face larger efficiency costs of distortionary taxation. In this paper, we show that the initial level of debt lowers public spending multipliers in normal times but raises public spending multipliers at the Zero Lower Bound (ZLB). In normal times, a spending shock financed by a 
combination of public debt and a distortionary tax rule leads to a larger increase in public debt and in future tax rates. This imposes more distortions on production factors and reduces the positive effects of a spending shock on output. At the ZLB, in line with Erceg and Lindé (2014), we find that a spending shock at the ZLB is self-financing. This leads public debt and future tax rates to fall, lowers the amount of distortions imposed on production factors, and further raises output. These movements are larger for economies featuring a high initial debt-to-GDP ratio due to their higher tax levels, and because the costs of taxation are convex. The shock leading the ZLB to be binding is here a negative capital quality shock, as in Gertler and Karadi (2011), but our results are robust to considering a discount factor shock. One important difference between capital quality shocks and discount factor shocks is that the latter produce a rise in private investment while the former produce a fall in private investment. We thus consider the former to be more consistent with the Great Recession narrative, and with the factors that most likely led nominal interest rates to hit the ZLB.

Our results are qualitatively robust to keeping the steady-state level of tax rates constant and using a steady-state lump-sum tax to finance the changing steady-state level of debt. They are only slightly attenuated quantitatively speaking. Indeed, what crucially matters for our results to hold is the size of the change in tax rates that is needed to ensure fiscal solvency after spending shocks. The latter is larger when the steady-state level of debt is higher. The change in tax rates is positive in the case of a spending shock hitting the economy around the steady state because debt rises, which in turn reduces the size of the public spending multiplier, and negative in the case of a spending shock hitting at the ZLB because public debt falls, which in turn raises the value of the spending multiplier. We also show that our results hold and are quantitatively magnified when introducing hand-to-mouth households.

Quantitatively speaking, our model produces public spending multipliers that line-up quite well with the literature (see Ramey (2019) for a recent overview). During normal times, short-run multipliers (at a 2 years horizon) roughly range from 0.2 to 0.3 for an empirically plausible calibration of the model. When the spending shock hits conditional on a negative capital quality shock that pushes the economy at the ZLB for a few quarters, short-run multipliers range from 1.4 to 1.45 for the same calibration. In any case, spending multipliers at the ZLB are larger than spending multipliers at the steady-state, as in Christiano, Eichenbaum, and Rebelo (2011) and the subsequent literature. The impact of the initial level of debt is relatively small for short-run multipliers at the steady state, but can be very large for short-run multipliers at the ZLB. These results are quantitatively but not qualitatively sensitive to a small subset of parameters such as the Frisch elasticity on labor supply, the degree of complementarity between public and private goods in the utility function of households, or the responsiveness of the tax rules. Finally, we show that the initial level of debt crucially affects the optimized response of government spending to a large crisis that pushes the economy to the ZLB. The size and persistence of the rise in public expenditure varies depending on the initial level of debt, which is only a consequence of the fact 
that the effects on output of changes in spending are stronger when the initial level of debt is higher.

Our paper relates to the literature on spending multipliers that questions how the economic environment may affect the latter. Empirically, one of the first papers to raise the question was Perotti (1999). More recently, the subject has been revived by Auerbach and Gorodnichenko (2012), investigating whether the business cycle position matters for the value of multipliers. Two papers, respectively by Corsetti, Meier, and Müller (2012) and by Ilzetzki, Mendoza, and Végh (2013) question more precisely the impact of debt or fiscal stress on spending output multipliers. Their results converge and conclude that fiscally stressed or highly indebted economies tend to be characterized by lower spending multipliers. Our results about the impact of the initial level of debt on the size of fiscal multipliers are in accordance with those results, as we find that a high level of debt lowers the spending multiplier. Further, according to Corsetti, Meier, and Müller (2012), when an economy experiences a financial crisis, spending multipliers are much larger than in normal times. If one admits that financial crises are more likely to lead to ZLB episodes, this result is also consistent with more theoretical contributions like Christiano, Eichenbaum, and Rebelo (2011) and the subsequent literature. Our results are also consistent with this empirical result, as we find that spending multipliers are larger during a financial crisis, triggered by a negative capital quality shock that pushes the economy at the ZLB. A recent paper by Boitani and Perdichizzi (2018) tests the joint conditional impact of recessions and the level of debt on the size of spending multipliers. Boitani and Perdichizzi (2018) find evidence of self-financing public spending shocks during recessions in Euro Area countries, and find that multipliers are larger in high deficit countries than in low deficit countries, providing empirical evidence in favor of our results.

Our paper also belongs to a model-based literature that investigates the effects of the ZLB on the size of fiscal multipliers, summarized and referenced in Eggertsson (2011). In particular, Erceg and Lindé (2014) find that fiscal policy becomes self-financing at the ZLB, a result that is also present in our paper and key to our main result. To our knowledge however, there are only very few papers questioning the effect of the initial debt level on the size of public spending multipliers. Corsetti, Kuester, Meier, and Müller (2013) do investigate this question but their analysis does not consider capital accumulation, and essentially focuses on the case of lump-sum taxes, while our main focus is on distortionary taxes. Along this dimension, our framework is closer to Nakata (2017), although we consider a richer model with capital accumulation, and our main focus is not on Ramsey equilibria but on the size of government spending multipliers and optimized policies. Our paper also echoes the recent contribution of Bilbiie, Monacelli, and Perotti (2018), who derive optimal spending policies at the ZLB with an additional focus on spending multipliers. However, they consider lump-sum taxes and do not investigate the impact of the initial level of debt on spending multipliers and optimized policies. 
The paper is organized as follows. Section 2 presents the model and details our calibration. Section 3 analyzes the Impulse Response Functions to spending shocks hitting at the steady state or conditional on a negative capital quality shock that pushes the economy at the ZLB, depending on whether the initial debt-to-GDP ratio and taxes are low or high. Section 4 summarizes our results by presenting the value of spending multipliers at various horizons and under the different cases considered, and produces an extensive sensitivity analysis. Section 5 investigates the design of optimized spending rules, and Section 6 concludes.

\section{Model}

Our framework builds on a standard New Keynesian model with capital accumulation, sticky prices, public goods entering the utility of households and a monetary policy that is restricted by a (zero) lower bound on the nominal interest rate. Public expenditure are financed through public debt and distortionary taxes on capital and labor income.

\section{$2.1 \quad$ Households}

Households choose consumption, labor supply, deposits and government bonds maximizing lifetime welfare

$$
E_{t}\left\{\sum_{s=t}^{\infty}\left(\beta^{s-t}\right) u\left(c_{s}, g_{s}, \ell_{s}\right)\right\},
$$

where $u_{\ell, t} \leq 0, u_{c, t} \geq 0$ and $u_{g, t} \geq 0$ are the first-order partial derivatives with respect to the private consumption, $c_{t}$, hours worked, $\ell_{t}$ and the amount of public spending, $g_{t}$. Parameter $\beta \in(0,1)$ denotes the subjective discount factor. Households optimize subject to the following budget constraint

$$
b_{t}^{g}+p_{t}\left((1+\mu) c_{t}+k_{t}\right)=r_{t-1} b_{t-1}^{g}+p_{t}\left(\left(1-\tau_{t}\right) w_{t} \ell_{t}+R_{t}^{k} k_{t-1}\right)+\Pi_{t}
$$

In this equation, $b_{t}^{g}$ denotes the nominal amount of government bonds that returns $r_{t}$ between period $t$ and period $t+1$. Further, $\mu$ is a (constant) distortionary tax on consumption, $w_{t}$ is the real wage, and $\tau_{t}$ is a distortionary tax on labor income. ${ }^{1}$ Variable $R_{k t}=1+\left(1-\eta_{t}\right)\left(r_{t}^{k}-\delta\right)$ is the after-tax real gross return on capital where $\eta_{t}$ is the capital income tax that comes with a deduction for capital depreciation $\delta$, and $r_{t}^{k}$ denotes the real rental rate on the capital stock. Finally, $\Pi_{t}$ comprises monopolistic profits from firms. An additional constraint to the optimization program is the law of capital accumulation

$$
k_{t}-(1-\delta) \xi_{t} k_{t-1}=i_{t}\left(1-\left(\varphi^{i} / 2\right) x_{t}^{2}\right)
$$

\footnotetext{
${ }^{1}$ The consumption tax rate is introduced in the model to allow for a more realistic baseline calibration. In particular, we want both capital and labor income tax rates to be on the increasing part of the Laffer Curve to allow these instruments to be effective in stabilizing the level of debt. However, $\mu$ will not be considered as an active policy instrument.
} 
where $i_{t}$ is the amount of investment in physical capital, $x_{t}=i_{t} / i_{t-1}-1$ is the growth rate of investment, and $\varphi_{i}>0$ controls the size of investment adjustment costs. The stock of capital is potentially affected by a quality shock $\xi_{t}$, that follows an AR1 process: $\xi_{t}=\left(1-\rho_{\xi}\right) \xi+\rho_{\xi} \xi_{t-1}+$

$\varepsilon_{\xi, t}$, where $\rho_{\xi} \in[0,1)$ and $\varepsilon_{\xi} \sim \mathcal{N}\left(0, \sigma_{\xi}^{2}\right)$. First-order conditions with respect to deposits, bonds and labor supply imply

$$
\begin{aligned}
E_{t}\left\{\beta_{t, t+1} r_{t} / \pi_{t+1}\right\} & =1, \\
u_{\ell, t}+\left(1-\tau_{t}\right) u_{c, t} w_{t} /(1+\mu) & =0
\end{aligned}
$$

where $\beta_{t, t+1}=\beta u_{c, t+1} / u_{c, t}$ and where $\pi_{t}=p_{t} / p_{t-1}$ is the inflation rate. The first equation prices government bonds. The second equation relates the marginal disutility of working to the real wage, expressed in terms of the marginal utility of consumption. We define $q_{t} p_{t} u_{c, t}$ as the Lagrangian multiplier associated with the capital accumulation constraint, and derive the following first-order conditions with respect to the capital stock and investment:

$$
\begin{aligned}
E_{t}\left\{\beta_{t, t+1}\left(q_{t+1}(1-\delta) \xi_{t+1}+\left(1-\eta_{t}\right) r_{t+1}^{k}+\eta_{t} \delta\right)\right\} & =q_{t}, \\
q_{t}\left(1-\left(\varphi^{i} / 2\right) x_{t}^{2}-\varphi^{i} x_{t}\left(1+x_{t}\right)\right)+E_{t}\left\{\beta_{t, t+1} q_{t+1} \varphi^{i} x_{t+1}\left(1+x_{t+1}\right)^{2}\right\} & =1 .
\end{aligned}
$$

\section{$2.2 \quad$ Firms}

A perfectly competitive representative firm produces a final consumption good $y_{t}$ using a continuum of intermediate goods indexed in $j \in[0,1]$, according to the following production function:

$$
y_{t}=\left[\int_{0}^{1} y_{t}(j)^{\frac{\theta-1}{\theta}} d j\right]^{\frac{\theta}{\theta-1}},
$$

where $y_{t}(j)$ denotes the time $t$ input of intermediate good $j$ and $\theta$ the elasticity of substitution across intermediate goods. The firm takes the price of output $p_{t}$ and the input price $p_{t}(j)$ as given. Profit maximization leads to the following first-order condition:

$$
y_{t}(j)=\left(p_{t}(j) / p_{t}\right)^{-\theta} y_{t}
$$

Substituting (8) into (9) yields the following relationship between the aggregate price level and the price of intermediate goods:

$$
p_{t}=\left[\int_{0}^{1} p_{t}(j)^{1-\theta} d j\right]^{\frac{1}{1-\theta}} .
$$

Intermediate good $j \in(0,1)$ is produced under monopolistic competition using capital $k_{t-1}$ and 
labor $\ell_{t}$ with the following production function:

$$
y_{t}(j)=\left(\xi_{t} k_{t-1}(j)\right)^{\iota} \ell_{t}(j)^{1-\iota}
$$

where $\iota \in(0,1)$ is the share of capital in value-added. Intermediate good producers rent the effective capital stock and hire workers in perfectly competitive markets. Profits are distributed to the households at the end of each period. Recalling that $r_{t}^{k}$ and $w_{t}$ denote the real rental rate on capital and the real wage, respectively, the real marginal cost of intermediate good producers is:

$$
s_{t}=\left(\iota^{\iota}(1-\iota)^{1-\iota}\right)^{-1}\left(r_{t}^{k}\right)^{\iota}\left(w_{t}\right)^{1-\iota} .
$$

Profits are $\left[p_{t}(j) / p_{t}-s_{t}\right] p_{t} y_{t}(j)$, where $p_{t}(j)$ is the price of the good produced by firm $j$ in period $t$. We assume there are Calvo price-setting contracts, where $1 /(1-\gamma)$ and $\gamma_{p}$ respectively represent the average length of contracts and an indexation parameter with respect to past inflation. The optimal pricing conditions are standard and therefore not reported.

\subsection{Government, Central Bank and Aggregation}

Given our assumptions regarding taxes, the budget constraint writes:

$$
b_{t}=r_{t} b_{t-1}+p_{t}\left(g_{t}-\tau_{t} w_{t} \ell_{t}-\eta_{t}\left(r_{k t}-\delta\right) k_{t-1}-\mu c_{t}\right)
$$

where $b_{t}$ is the amount of nominal bonds issued by the government. Expressed in real terms, the budget constraint writes

$$
b_{t}^{r}=r_{t} b_{t-1}^{r} / \pi_{t}+g_{t}-\tau_{t} w_{t} \ell_{t}-\eta_{t}\left(r_{k t}-\delta\right) k_{t-1}-\mu c_{t} .
$$

where $b_{t}^{r}=b_{t} / p_{t}$. The stability of the debt-to-GDP ratio in the long run is ensured by the following tax rules:

$$
\begin{aligned}
\tau_{t} & =\tau+d_{\tau}\left(b_{t-1}^{r}-b^{r}\right) \\
\eta_{t} & =\eta+d_{\eta}\left(b_{t-1}^{r}-b^{r}\right),
\end{aligned}
$$

where the parameters $d_{\tau}$ and $d_{\eta}$ respectively measure the responsiveness of the labor income tax and the capital income tax to the deviation of the ratio from its initial steady state value. Government spending evolve following a standard AR(1) process:

$$
\log \left(g_{t} / g\right)=\rho_{g} \log \left(g_{t-1} / g\right)+\varepsilon_{g, t},
$$

where $\rho_{g} \in[0,1)$ and $\varepsilon_{g} \sim \mathcal{N}\left(0, \sigma_{g}^{2}\right)$, and where $g$ is the initial steady state level of government expenditure. The Central Bank sets the gross nominal interest rate $r_{t}$ according to 


$$
r_{t}=\max \left(1, r n_{t}\right)
$$

where $r n_{t}$ is the desired gross nominal interest rate that evolves according to:

$$
\log \left(r n_{t} / r\right)=d_{\pi} \log \left(\pi_{t} / \pi\right)+d_{y} \log \left(y_{t} / \widetilde{y}_{t}\right)
$$

In the above equation, $\pi_{t}$ is the inflation rate and $\widetilde{y}_{t}$ is the natural level of output. ${ }^{2}$ Parameters $d_{\pi}$ and $d_{y}$ are the elasticities of $r n_{t}$ to inflation and the output gap, respectively. The central bank sets $r_{t}$ equal to $r n_{t}$ if and only if its policy rule implies a non-negative level for the nominal interest rate. Otherwise, the ZLB binds and $r_{t}$ equals one. A competitive equilibrium in our model is defined as a situation where $(i)$ households and firms optimize for a given path of policy instruments, and $(i i)$ prices clear markets according to:

$$
\begin{aligned}
\text { Intermediate goods: } & \left(\xi_{t} k_{t-1}\right)^{\iota} \ell_{t}^{1-\iota}=\int_{0}^{1} y_{t}(j) d j=y_{t} d p_{t}, \\
\text { Final goods: } & y_{t}=c_{t}+i_{t}+g_{t} \\
\text { Government bonds: } & b_{t}=b_{t}^{g} \\
\text { Deposits: } & d_{t}=0
\end{aligned}
$$

where $d p_{t}=\int_{0}^{1}\left(p_{t}(j) / p_{t}\right)^{-\theta} d j \geq 1$ measures the dispersion of prices.

\subsection{Calibration and set-up}

The model is quarterly and our calibration is intended to capture an average OECD country. We adopt a formulation of the utility where private and public goods provide direct utility:

$$
u\left(c_{t}, g_{t}, n_{t}\right)=\log \left(\widetilde{c}_{t}\right)-\omega \ell_{t}^{1+\psi} /(1+\psi)
$$

where

$$
\widetilde{c}_{t}=\left(\kappa c_{t}^{\frac{\nu-1}{v}}+(1-\kappa) g_{t}^{\frac{\nu-1}{v}}\right)^{\frac{\nu}{\nu-1}}, \nu>0 .
$$

In equation (25), $\kappa$ denotes the weight of private consumption in the effective consumption index, and $\nu$ is the elasticity of substitution between the private and the public good. When $\nu=0$, public and private goods are pure complements. As $\nu$ increases, private and public goods become more and more substitutable, and pure substitutability arises when $\nu \rightarrow \infty$. This specification is in the spirit of Leeper, Traum, and Walker (2015), but our choice of a CES specification is justified by the need to capture the diminishing marginal returns to public spending in order to achieve a given level of effective consumption, ceteris paribus. Empirical evidence favor estimates pointing to a mild complementarity (see Bouakez and Rebei (2007)) and we set $\nu=0.45$ in the

\footnotetext{
${ }^{2}$ As in Gertler and Karadi (2011), variations in the mark-up serve as a proxy for variations in the output gap.
} 
benchmark calibration. ${ }^{3}$ We also impose the value of $\kappa$ so that the marginal utilities of private and public goods are equal in the steady state, an application of Samuelson's principle. ${ }^{4}$

The discount factor is $\beta=0.99$ implying an annual real interest rate of 4.1 percents. The inverse of the Frisch elasticity of labor supply is typically a controversial and important parameter. We impose $\psi=3$ to capture relatively sluggish labor markets, a value that lies in-between the calibration of Corsetti et al. (2013) and that of Galí, López-Salido, and Vallés (2007). Because this parameter is both non-consensual, and key in generating our results, a sensitivity analysis will be conducted. On the production side, the share of capital is $\iota=0.33$, and the steadystate depreciation rate is $\delta=0.018$ (7\% annually). The investment adjustment cost parameter, $\varphi_{i}$, is set to 1.8 . The steady-state mark-up is $30 \%$, implying $\theta=4.33$, the Calvo parameter on price contracts is $\gamma=0.75$ a standard value in quarterly models of price adjustments, and the indexation parameter is $\gamma_{P}=0.5$. The feedback parameters of the fiscal rules are $d_{\tau}=$ $d_{\eta}=0.1$, which ensures medium-run fiscal solvency, and makes fiscal policy passive in the sense of Leeper (1991). These values are quite larger than usually estimated to built intuition. Given their importance in generating our results, a sensitivity analysis with respect to these parameters will be conducted. Parameters of the Taylor rule are $d_{\pi}=1.5$ and $d_{y}=0.125$ and the persistence parameters of shocks are $\rho_{\xi}=0.7$ and $\rho_{g}=0.85$. In the baseline calibration, we impose $b^{g} /(4 y)=0.8$ and adjust the value of $\omega$ to get $\ell=0.3$. Both targets are realistic when it comes to match observed values in OECD countries. Whenever the debt-output ratio is varied, $\omega$ remains unchanged. In line with OECD averages, the share of public consumption in GDP is $s_{g}=g / y=0.2$, the capital income tax rate is $\eta=0.2$, the consumption tax rate is $\mu=0.15$ and the labor income tax rate is adjusted to match the debt-to-GDP ratio target, implying $\tau=0.2207$ when $b^{g} /(4 y)=0.8$, a number well within OECD average labor income tax measures. Table 1 summarizes our parameter values.

In the next paragraphs we consider various steady-state levels of debt-to-GDP ratios $b^{g} /(4 y)$. When varying $b^{g} /(4 y)$, we let the labor income tax rate adjust to maintain fiscal solvency in the steady state. This approach is backed by a quick glance at the data. Indeed, we show in Appendix A that debt-to-GDP ratios relate positively to labor income taxes across years and countries, using two separate datasets. ${ }^{5}$ In any case our results are also robust to keeping the steady-state labor income tax rate constant and using a steady-state lump-sum tax to keep the government budget constraint in balance when varying the steady-state level of public debt (see

\footnotetext{
${ }^{3}$ This second value is also broadly consistent with the point estimates found by Auray and Eyquem (2017), between 0.5 and 0.6, and with the estimates of Leeper, Traum, and Walker (2015), according to which public and private goods are complements.

${ }^{4}$ The value of $\kappa$ that is consistent with the optimal provision of public good in the steady-state is indeed $u_{c}=u_{g}$ and implies:

$$
\kappa=g^{-\frac{1}{\nu}} /\left(c^{-\frac{1}{\nu}}+g^{-\frac{1}{\nu}}\right) .
$$

${ }^{5}$ The relation is less clear for consumption tax rates but we do not consider this instrument in our analysis.
} 
Table 1: Baseline parameter values

\begin{tabular}{lr}
\hline \hline Discount factor & $\beta=0.99$ \\
Edgeworth preference parameter & $\nu=0.45$ \\
Inverse of the Frisch elasticity of labor supply & $\psi=3$ \\
Steady-state depreciation rate of capital & $\delta=0.018$ \\
Production function, capital parameter & $\iota=0.33$ \\
Investment adjustment cost parameter & $\varphi_{i}=1.8$ \\
Steady-state mark-up & $\theta /(\theta-1)=1.3$ \\
Calvo parameter & $\gamma=0.75$ \\
Indexation parameter & $\gamma^{p}=0.5$ \\
Fraction of time spent working & $\ell=0.3$ \\
Labor disutility parameter & $\omega=$ adjusted \\
Government debt to annual GDP & $b^{g} /(4 y)=0.8$ \\
Government spending to GDP & $s_{g}=0.2$ \\
Labor income tax rate & $\tau=0.2207$ \\
Capital income tax rate & $\eta=0.2$ \\
Consumption tax rate & $\mu=0.15$ \\
Tax rule parameters & $d_{\tau}=d_{\eta}=0.1$ \\
Taylor rule, response to inflation & $d_{\pi}=1.5$ \\
Taylor rule, response to output gap & $d_{y}=0.125$ \\
Persistence of public spending shock & $\rho_{g}=0.85$ \\
Persistence of capital quality shock & $\rho_{\xi}=0.7$ \\
\hline \hline
\end{tabular}

Figure 6 in Appendix B).

\section{Impulse response functions}

In the following experiments, we investigate the responses of our model economy under two polar cases for the debt level, $b^{g} /(4 y)=0.6$ referred to as the case of low debt, and $b^{g} /(4 y)=1.15$, referred to as the case of high debt. In each case, the calibration remains the same except for the steady-state level of debt and for the labor or capital income tax rate. In particular, the labor disutility parameter $\omega$ remains unchanged, so when tax rates change the steady-state level of hours worked, capital and output change as well. We get $\tau=0.2050$ in the case of low debtto-GDP ratio and $\tau=0.2481$ when the steady-state ratio is high. These numbers are reasonable in comparison to observed labor and capital income tax rates in OECD countries (See Appendix A).

\subsection{Public spending shocks}

Figure 1 reports the Impulse Response Functions (IRFs hereafter) of the economy to a one percent public spending shock with a labor income tax rule. The top panel reports the dynamics when the shock hits at the steady state while the bottom panel reports the dynamics conditional on a $5 \%$ capital quality shock that depresses the economy and pushes the nominal interest rate to 
the ZLB. ${ }^{6}$ The model is simulated using the fully non-linear model under perfect foresight, based on a Newton-Raphson algorithm. ${ }^{7}$ Even though we solve under perfect foresight, the shock that hits in period 1 is a surprise to the agents. Therefore, because there are only shocks at period 1 under all our simulations, the model solution captures accurately the relevant non-linearities of the model, including the ZLB constraint. The black solid line shows the response of the economy with a low steady-state debt-to-GDP ratio $(60 \%)$ while the red line shows the response with a high ratio $(115 \%)$.

The top panel of Figure 1 shows that a spending shock has positive effects on output, does not crowd out private consumption much (remember that public and private goods are complements), and lowers investment. The real wage and hours worked both increase since the demand for final goods rises, as shown by the rise in the inflation rate. In terms of public finance, both public debt to GDP and tax rates increase, which contributes to moderate the rise in hours worked further crowd-out private investment compared to the case of lump-sum taxes. ${ }^{8}$ The most interesting feature of this figure lies in the differences between a low or a high steady-state debt-to-GDP ratio. With a high steady-state ratio, a public spending shock leads the debt-output ratio to rise much more than with a low initial ratio. For a given dynamics of the nominal interest rate, a country with a higher debt-output ratio faces a larger rollover cost when debt increases, which requires a larger subsequent fiscal adjustment. In addition, a country with a high level of debt also faces a higher level of taxes. Since the cost of taxation is convex, the tax rate has to increase more to produce the required increase in government revenue. Thus, the shock induces both the labor income tax rate and the capital income tax rate to increase more, imposing larger distortions on hours worked, private investment and hence on output. The dynamics of the real wage is further marginally less positive in this case, which translates into slightly smoother inflation and nominal interest rate dynamics.

Let us now focus on the case where the public spending shock hits conditional on a crisis. The latter is triggered by a $5 \%$ capital quality shock. The dynamics generated by the public spending shock conditional on a crisis is obtained by taking the difference between the joint shock and a crisis shock only. The bottom panel of Figure 1 thus reports the net effects of the public spending shock.

\footnotetext{
${ }^{6}$ Appendix B provides the IRFs to this shock only. In line with Gertler and Karadi (2011), a capital quality shock induces a fall in output, consumption, investment, real wages, hours worked, the price of equity, and inflation, pushing the economy to the ZLB for 4 quarters. It also raises public debt and tax rates. While Gertler and Karadi (2011) set a smaller shock value, notice that our model does not feature banking frictions and therefore requires a larger innovation to produce a similar negative output dynamics - as well as a binding ZLB.

${ }^{7}$ The algorithm is a built-in routine of Dynare 4.5.1 (Adjemian et al. (2011)). It is an application of the NewtonRaphson algorithm that takes into consideration the special structure of the Jacobian matrix in dynamic models with forward-looking variables. The details of the algorithm are explained in Juillard (1996). The algorithm does not rely on linearization.

${ }^{8}$ IRFs under lump-sum taxes do not show any difference whether debt is high or low, under any of the situations we consider. These IRFs are available upon request.
} 
Figure 1: IRFs to a $1 \%$ public spending shock.

At steady state.

(a) Output

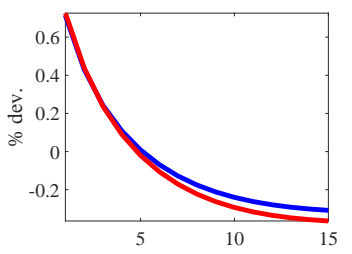

(e) Real wage

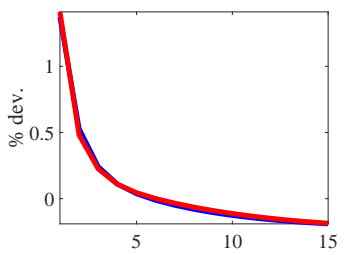

(i) Real int. rate

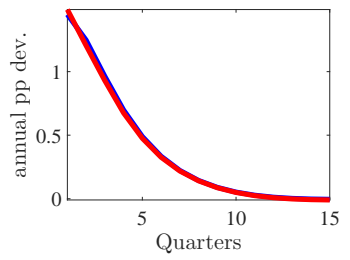

(m) Output

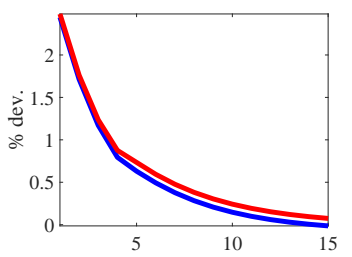

(q) Real wage

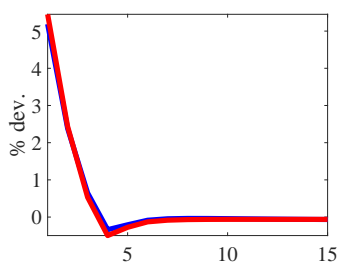

(u) Real int. rate

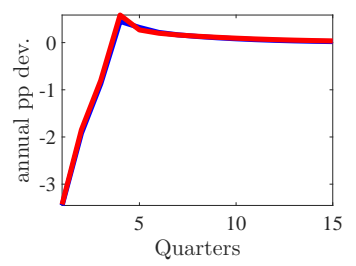

(c) Investment

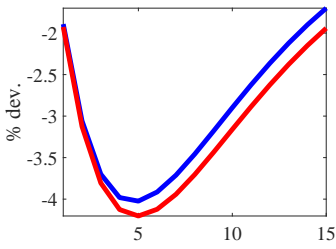

(g) Inflation rate

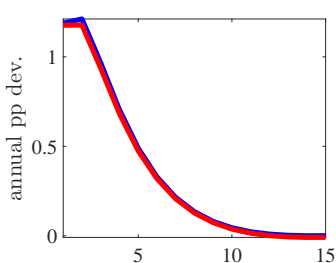

(k) Labor tax

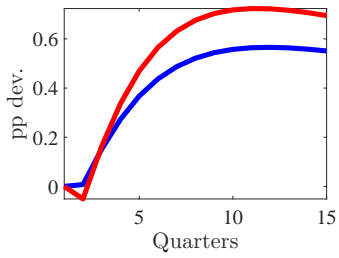

At ZLB

(n) Consumption

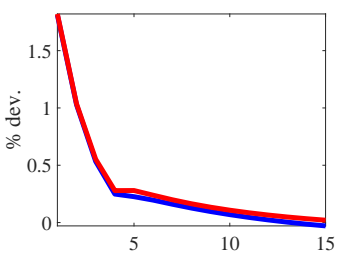

(r) Price of capital

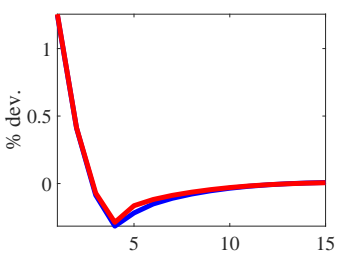

(v) Debt to GDP
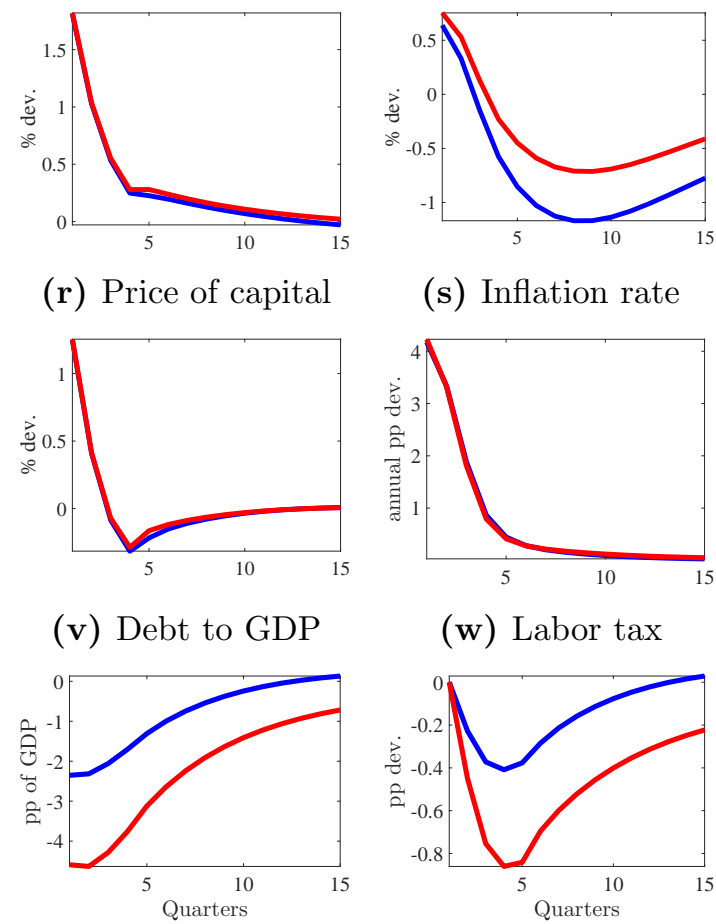

(s) Inflation rate

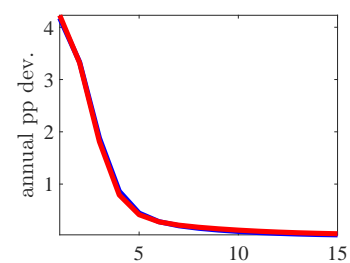

(w) Labor tax

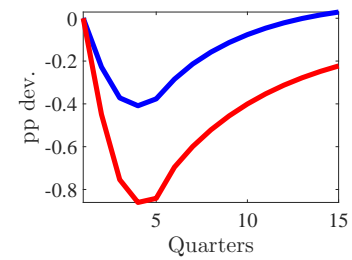

(d) Hours worked

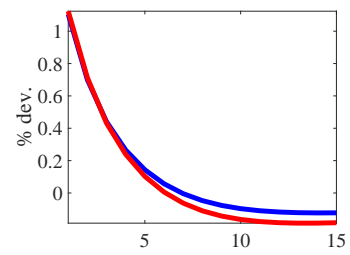

(h) Nominal int. rate

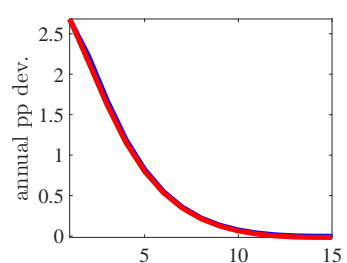

(1) Capital tax

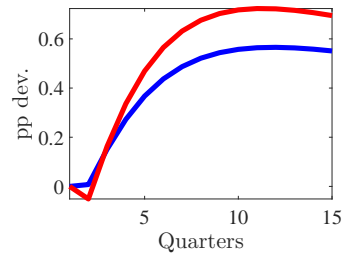

(p) Hours worked

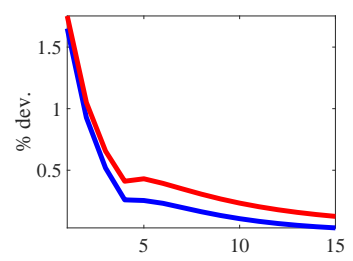

(t) Nominal int. rate

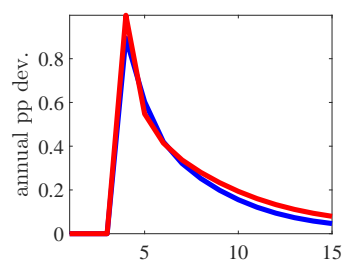

(x) Capital tax

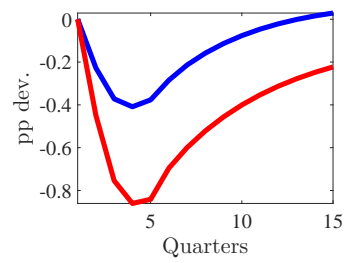

Black: $b^{g} /(4 y)=0.6$ and $\tau=0.2050$. Red: $b^{g} /(4 y)=1.15$ and $\tau=0.2481$. 
On impact, when the ZLB is strictly binding, an increase in government spending leads to a rise in output, marginal cost, and inflation. The increase in expected inflation lowers the real interest rate, which drives up private consumption much more than when the shock hits at the steady state. This rise in private consumption expenditure leads to a further rise in output, marginal cost, and expected inflation and a further decline in the real interest rate. In addition, at the ZLB, the price of capital rises instead of falling which also boosts private investment instead of depressing it. These results line up very well with the findings of Christiano, Eichenbaum, and Rebelo (2011). Interestingly enough, output increases more in the case of a high initial debt-to-GDP ratio, leading to a larger value of the government spending multiplier. We explain these results in the following way.

When a government spending shock hits at the ZLB, consumption is more strongly crowded-in and private investment is crowded-in instead of being crowded-out. Aggregate demand is thus boosted by much more, which results in a massive rise in labor demand: hours worked and the real wage both rise more at the ZLB. Hours increase by more than $1.5 \%$ (instead of $1 \%$ out of the ZLB) and the real wage increases by more than $4 \%$ (instead of $1.5 \%$ ). These effects are clearly not new and explained extensively in several papers (see Christiano, Eichenbaum, and Rebelo (2011) and the subsequent literature). In addition, as in Erceg and Lindé (2014), fiscal policy becomes self-financing because tax bases increase massively. Hence, the debt-to-GDP ratio falls instead of rising, triggering a fall in the labor and capital income tax rates. The latter further boost the economy by lowering the overall distortions on labor supply and capital accumulation. Finally, because countries with a higher debt level also have a higher tax level, and because the costs of taxation are convex, these movements are larger for economies featuring a large initial debt-to-GDP ratio. Therefore, when the public spending shock hits at the ZLB and produces a fall in the debt-to-GDP ratio, the high-debt economy features a larger public spending multiplier. We expect this result to be sensitive to the labor supply elasticity, as the strength of tax base dynamics depends on how much households are willing to increase their labor supply after a spending shock, but also to the parameters of the tax rules.

\subsection{Robustness}

Do our results depend on adjusting the steady-state labor income tax rate when varying the steady-state level of debt? Figure 6 in Appendix B shows that they do not. Figure 6 replicates Figure 1 keeping the steady-state labor income tax rate constant and using a steady-state lumpsum tax to keep the government budget constraint balanced in the steady state. Our results remain basically unchanged. Indeed, crucial to our results is the change in the tax rates after a spending shock, not the level of the tax rates. Changes in public debt are larger when steadystate levels of public debt are higher, which requires larger changes in tax rates to stabilize public debt, which reduces the spending multiplier when the spending shock hits at the steady state and raises the spending multiplier when the shock hits at the ZLB. 
Another potential extension is the inclusion of rule-of-thumb, or hand-to-mouth households, as in Galí, López-Salido, and Vallés (2007), as this assumption matters for the transmission of fiscal policy shocks. In this case, we consider two types of households. The optimizing households behave exactly as exposed in the model section, while the constrained, or hand-tomouth households, do not have access to financial markets, and therefore do not accumulate government bonds or capital. As such, they simply consume their current-period income. While they supply labor in a similar way as optimizing households, their consumption is determined by their budget constraint:

$$
\begin{aligned}
u_{\ell^{r}, t}+\left(1-\tau_{t}\right) u_{c^{r}, t} w_{t} /(1+\mu) & =0 \\
(1+\mu) c_{t}^{r}-\left(1-\tau_{t}\right) w_{t} \ell_{t}^{r} & =0
\end{aligned}
$$

where $\ell_{t}^{r}$ and $c_{t}^{r}$ respectively denote the hours worked by optimizing households and their consumption level. The first-order conditions given by equations (4)-(5) now apply to $\ell_{t}^{o}$ and $c_{t}^{o}$, that respectively represent the hours worked by optimizing households and their consumption level. Both types of households face the same labor income tax rate, and the same real wage. Finally, aggregate hours worked and aggregate consumption are then given by $\ell_{t}=\lambda \ell_{t}^{o}+(1-\lambda) \ell_{t}^{r}$ and $c_{t}=\lambda c_{t}^{o}+(1-\lambda) c_{t}^{r}$, where $\lambda$ is the constant proportion of optimizing households in the economy. We impose $\lambda=0.75$, and recalibrate the model - essentially the labor disutility parameters to get $\ell=\ell^{o}=\ell^{r}=0.3$ in the steady state. Keeping the rest of the calibration unchanged, the model with hand-to-mouth households implies $c^{o}=0.6390$ and $c^{r}=0.2970$ in the steady state. Further, Figures 7 and 8 in Appendix B replicate both panels of Figure 1 with optimizing and hand-to-mouth households.

Figures 7 and 8 show that our results are preserved and even magnified by the introduction of hand-to-mouth households. Let us first look at the effects of a spending shock at the steady state. As shown already, spending shocks raise the real wage, which allows hand-to-mouth households to raise their consumption level. As a result, aggregate consumption is less crowded out, and investment more crowded out than in our baseline model. In addition, the increase in hours worked is slightly larger with hand-to-mouth households, as a result of a larger increase of the real wage. Notice however that hand-to-mouth households, because they experience a rise in their consumption level, increase their hours worked only by a very small amount due to the wealth effect. The effects of a spending shock at the steady state are thus in the same ballpark than in our baseline model, and qualitatively similar: the output effects of a government spending shock are larger when the initial level of debt is smaller, because the response of tax rates remains qualitatively unchanged. They must rise because the spending shock raises pubic debt, and more so with a large initial level of debt. Let us now discuss the effects of spending shocks with handto-mouth households at the ZLB. In this case too, the rise in the real wage is almost transmitted one for one to the consumption of hand-to-mouth households, they experience a small rise in 
their level of hours worked, but the very large (6\%) rise in their consumption level contributes to raise aggregate consumption and aggregate output by more than in our baseline model. The output effects of a spending shock at the ZLB are thus larger with hand-to-mouth households. Since the real wage rises more and since aggregate hours worked rise more than in our baseline model, the tax base expands more which implies a larger fall in the tax rates, especially the labor income tax rate, both for low and high initial levels of public debt. As such, the output effects are both larger but the difference is also larger. If anything, the introduction of hand-to-mouth households thus amplifies our main result. ${ }^{9}$

\section{Government spending multipliers}

We now investigate more systematically the extent to which the initial debt-to-GDP ratio affects the value of present-value public spending multipliers. While the impact multiplier is an important measure of the effectiveness of fiscal policy, looking at longer horizons matters insofar the dynamics of subsequent fiscal adjustments matters for the overall effectiveness of fiscal policy. Our preferred measure will therefore be the present-value multiplier at different horizons. The latter is defined as the discounted cumulative increase in output over $T$ periods that results from the discounted cumulative increase in public spending over $T$ periods after a spending shock in period 1:

$$
P V M_{T}=\frac{\sum_{j=1}^{T} \beta^{j}\left(y_{t+j}-y_{t}\right)}{\sum_{j=1}^{T} \beta^{j}\left(g_{t+j}-g_{t}\right)} .
$$

Table 2 below reports the values of the present-value multipliers at 2 years $(T=8)$ and at 5 years $(T=20)$ under various configurations, when the shock hits at the steady state or conditional on a crisis. We consider both a labor income tax rule and a capital income tax rule, and investigate the sensitivity of our result to the Edgeworth complementarity parameter, to the Frisch elasticity of labor supply and to the strength of the response of tax rates in the tax rules.

Quantitatively speaking, multipliers at 2 years broadly range from 0.05 to 0.5 when the shock hits at the steady state, and from 0.6 to 1.5 at the ZLB. These intervals are wide but the value of multipliers is crucially affected by the complementarity parameter $\nu$ and by the labor supply elasticity $1 / \psi$. Empirically, $\nu$ and $\psi$ are more likely to be close to the baseline calibrated values $\nu=0.45$ and $\psi=3$, suggesting multipliers at 2 years between 0.18 and 0.29 at the steady state, and between 1.4 and 1.45 at the ZLB. These are relatively consensual values in the literature.

As already suggested by the analysis of the IRFs, multipliers at the ZLB are much larger than multipliers at the steady state, both at the horizon of 2 years and 5 years. This statement is true both at low and high levels of debt. While this result may not be new, the fact that multipliers

\footnotetext{
${ }^{9}$ See also Table 2 for the size of multipliers at different horizon with hand-to-mouth households.
} 
Table 2: Multipliers at different horizons.

\begin{tabular}{|c|c|c|c|c|c|c|c|c|}
\hline & \multicolumn{8}{|c|}{$c_{t}$ and $g_{t}$ complements $(\nu=0.45)$} \\
\hline & \multicolumn{4}{|c|}{ Low debt $\left(b^{g} /(4 y)=0.6\right)$} & \multicolumn{4}{|c|}{ High debt $\left(b^{g} /(4 y)=1.15\right)$} \\
\hline & \multicolumn{2}{|c|}{ Steady state } & \multicolumn{2}{|c|}{ ZLB } & \multicolumn{2}{|c|}{ Steady state } & \multicolumn{2}{|c|}{ ZLB } \\
\hline & 2 years & 5 years & 2 years & 5 years & 2 years & 5 years & 2 years & 5 years \\
\hline$\psi=3$ & 0.207 & -0.263 & 1.403 & 1.124 & 0.177 & -0.359 & 1.492 & 1.321 \\
\hline$\psi=2$ & 0.308 & -0.196 & 1.363 & 1.079 & 0.277 & -0.298 & 1.480 & 1.326 \\
\hline$\psi=1$ & 0.494 & -0.061 & 1.191 & 0.848 & 0.468 & -0.159 & 1.292 & 1.059 \\
\hline$d_{\tau}=d_{\eta}=0.05$ & 0.255 & -0.131 & 1.426 & 1.164 & 0.239 & -0.188 & 1.470 & 1.286 \\
\hline$d_{\tau}=d_{\eta}=0.04$ & 0.265 & -0.099 & 1.424 & 1.162 & 0.253 & -0.146 & 1.464 & 1.269 \\
\hline$d_{\tau}=d_{\eta}=0.03$ & 0.275 & -0.064 & 1.420 & 1.156 & 0.266 & -0.100 & 1.453 & 1.244 \\
\hline$d_{\tau}=d_{\eta}=0.02$ & 0.286 & -0.027 & 1.413 & 1.146 & 0.280 & -0.052 & 1.437 & 1.210 \\
\hline$d_{\tau}=0.1, d_{\eta}=0$ & 0.232 & -0.194 & 1.389 & 1.119 & 0.210 & -0.271 & 1.452 & 1.269 \\
\hline$d_{\tau}=0.05, d_{\eta}=0$ & 0.273 & -0.073 & 1.424 & 1.164 & 0.263 & -0.114 & 1.460 & 1.257 \\
\hline \multirow[t]{5}{*}{$d_{\tau}=0.02, d_{\eta}=0$} & 0.295 & 0.006 & 1.416 & 1.148 & 0.291 & -0.011 & 1.437 & 1.196 \\
\hline & \multicolumn{8}{|c|}{$c_{t}$ and $g_{t}$ substitutes $(\nu=1)$} \\
\hline & \multicolumn{4}{|c|}{ Low debt $\left(b^{g} /(4 y)=0.6\right)$} & \multicolumn{4}{|c|}{ High debt $\left(b^{g} /(4 y)=1.15\right)$} \\
\hline & \multicolumn{2}{|c|}{ Steady state } & \multicolumn{2}{|c|}{ ZLB } & \multicolumn{2}{|c|}{ Steady state } & \multicolumn{2}{|c|}{ ZLB } \\
\hline & 2 years & 5 years & 2 years & 5 years & 2 years & 5 years & 2 years & 5 years \\
\hline$\psi=3$ & 0.057 & -0.301 & 0.765 & 0.501 & 0.039 & -0.359 & 0.864 & 0.672 \\
\hline$\psi=2$ & 0.092 & -0.318 & 0.705 & 0.407 & 0.073 & -0.381 & 0.826 & 0.615 \\
\hline$\psi=1$ & 0.158 & -0.351 & 0.584 & 0.195 & 0.141 & -0.412 & 0.709 & 0.414 \\
\hline$d_{\tau}=0.05$ & 0.106 & -0.171 & 0.782 & 0.561 & 0.096 & -0.205 & 0.836 & 0.662 \\
\hline$d_{\tau}=0.04$ & 0.116 & -0.138 & 0.785 & 0.573 & 0.109 & -0.167 & 0.829 & 0.657 \\
\hline$d_{\tau}=0.03$ & 0.127 & -0.104 & 0.787 & 0.585 & 0.121 & -0.126 & 0.820 & 0.650 \\
\hline$d_{\tau}=0.02$ & 0.138 & -0.066 & 0.789 & 0.597 & 0.134 & -0.081 & 0.811 & 0.642 \\
\hline$d_{\tau}=0.1, d_{\eta}=0$ & 0.078 & -0.238 & 0.756 & 0.516 & 0.064 & -0.285 & 0.842 & 0.657 \\
\hline$d_{\tau}=0.05, d_{\eta}=0$ & 0.121 & -0.117 & 0.777 & 0.574 & 0.114 & -0.143 & 0.824 & 0.655 \\
\hline \multirow[t]{5}{*}{$d_{\tau}=0.02, d_{\eta}=0$} & 0.146 & -0.036 & 0.786 & 0.605 & 0.144 & -0.046 & 0.807 & 0.639 \\
\hline & \multicolumn{8}{|c|}{$c_{t}$ and $g_{t}$ complements $(\nu=0.45)+$ hand-to-mouth households* } \\
\hline & \multicolumn{4}{|c|}{ Low debt $\left(b^{g} /(4 y)=0.6\right)$} & \multicolumn{4}{|c|}{ High debt $\left(b^{g} /(4 y)=1.15\right)$} \\
\hline & \multicolumn{2}{|c|}{ Steady state } & \multicolumn{2}{|c|}{ ZLB } & \multicolumn{2}{|c|}{ Steady state } & \multicolumn{2}{|c|}{ ZLB } \\
\hline & 2 years & 5 years & 2 years & 5 years & 2 years & 5 years & 2 years & 5 years \\
\hline$\psi=3$ & 0.184 & -0.291 & 1.582 & 1.281 & 0.144 & -0.406 & 1.715 & 1.509 \\
\hline$\psi=2$ & 0.292 & -0.211 & 1.535 & 1.237 & 0.251 & -0.332 & 1.722 & 1.555 \\
\hline$\psi=1$ & 0.483 & -0.066 & 1.419 & 1.107 & 0.447 & -0.184 & 1.671 & 1.541 \\
\hline$d_{\tau}=0.05$ & 0.226 & -0.180 & 1.552 & 1.265 & 0.203 & -0.252 & 1.620 & 1.399 \\
\hline$d_{\tau}=0.04$ & 0.236 & -0.151 & 1.545 & 1.259 & 0.217 & -0.212 & 1.598 & 1.370 \\
\hline$d_{\tau}=0.03$ & 0.246 & -0.118 & 1.537 & 1.252 & 0.231 & -0.167 & 1.576 & 1.338 \\
\hline$d_{\tau}=0.02$ & 0.257 & -0.082 & 1.528 & 1.244 & 0.245 & -0.117 & 1.554 & 1.302 \\
\hline$d_{\tau}=0.1, d_{\eta}=0$ & 0.206 & -0.231 & 1.552 & 1.259 & 0.175 & -0.326 & 1.658 & 1.443 \\
\hline$d_{\tau}=0.05, d_{\eta}=0$ & 0.243 & -0.126 & 1.531 & 1.248 & 0.226 & -0.180 & 1.586 & 1.350 \\
\hline$d_{\tau}=0.02, d_{\eta}=0$ & 0.266 & -0.050 & 1.517 & 1.235 & 0.258 & -0.075 & 1.539 & 1.277 \\
\hline
\end{tabular}

*: The share of hand-to-mouth households is $1-\lambda=0.25$. 
are large at the ZLB are clearly the explanation for the fact that fiscal policy becomes selffinancing (see Erceg and Lindé (2014)), leading public debt to fall and future tax rates to drop as well. Because of their distortionary nature, this in turn impacts the dynamics of factor prices and quantities, and then the dynamics of output. Indeed, when the shock hits at the steady state, multipliers are either slightly lower (2 years) or substantially lower (5 years) in the high debt economy, because debt and taxes increase after the shock. The pattern reverses at the ZLB because debt and taxes fall after the shock. These results hold qualitatively for all the parameter values considered in Table 2 .

In addition, when public and private goods are complements, multipliers are always larger whatever the configuration or the calibration. This too shall not be surprising as an increase in public spending crowds-in consumption (at the ZLB) or reduces consumption crowding-out (at the steady state) when goods are complements, while consumption is clearly crowded-out when goods are substitutes. However, as will be clear when discussing the role of key parameters such as the labor supply elasticity, whether goods are complements or substitutes is far from neutral, as this not only affects the dynamics of consumption but also that of labor supply and aggregate demand.

The implication of having a significant part (25\%) of the household that are financially constrained or hand-to-mouth on multipliers depends on whether the spending shock hits at the steady state or conditionally on a shock that pushes the economy to the ZLB. At the steady state, spending multipliers are lower than without hand-to-mouth agents. Because part of aggregate consumption is more clearly crowded-in after a spending shock, private investment falls more. While both effects have opposite implications for the size of spending multipliers, the second effect dominates and the multiplier is smaller than without hand-to-mouth agents. Further, our result according to which a larger initial debt level is associated with a lower multiplier is preserved, and the difference between multipliers at low vs. higher initial levels of debt remains broadly unchanged. At the ZLB, the presence of hand-to-mouth agents increases the size of spending multipliers: because of the dynamics of the real interest rate at the ZLB, investment is not crowded out anymore and the first effect - larger crowding in of private consumption - dominates. Again, this turns out to comfort our results according to which the spending multiplier is larger with higher initial levels of public debt at the ZLB. In addition, because the presence of hand-to-mouth agents raises the absolute value of multipliers at the ZLB, the difference between multipliers at low and high debt levels increases.

Let us now discuss the implications of some key parameters on our results, starting with the labor supply elasticity $1 / \psi$. First, when labor becomes more elastic, labor supply becomes more sensitive to the variations of the after-tax real wage. This is the direct effect through which a more elastic labor supply (lower $\psi$ ) raises labor supply and thus output in the short run after a spending shock. It also lowers labor supply and thus output more in the medium run after an 
increase in the tax rate, that lowers the after-tax real wage. Second, when labor supply becomes more elastic, the real wage rises less after a spending shock, as the labor supply curve is flatter. It attenuates the rise in the equilibrium real wage, the rise in private consumption and the rise in aggregate demand. As such, it contributes negatively to aggregate output. This indirect effect is stronger when consumption is crowded-in after a spending shock, that is, when public and private goods are complements $(\nu<1)$ or at the ZLB. Clearly, short-run multipliers $(2$ year) at the steady state are always larger when labor becomes more elastic, as the direct effect dominates. On the contrary, short-run multipliers at the ZLB are always lower when labor supply becomes more elastic, as the indirect effect dominates since consumption is strongly crowded-in. This pattern also applies to medium run (5 years) multipliers.

We now shift the discussion to the impact of tax rule parameters $d_{\tau}$ and $d_{\eta}$. The baseline calibrated value is quite larger than suggested by the empirical estimates, a choice that was made to illustrate our main results graphically. ${ }^{10}$ However, Table 2 shows very clearly that our main result remains qualitatively unchanged when considering more realistic values of $d_{\tau}$ and $d_{\eta}$. When the spending shock hits at the steady state, a less aggressive response of taxes raise the value of multipliers. Public debt increases after the shock, so a larger rise of tax rates implies more distortions imposed on labor or capital, and therefore lower multipliers. When the shock hits at the ZLB, less aggressive tax rules actually lower the value of multipliers. As already explained and shown in Figure 1, fiscal policy becomes self-financing at the ZLB and a spending shock implies a large rise in tax bases. Public debt falls, and if taxes respond less firmly to those changes in public debt, they fall less and subsequently produce a smaller fall in the distortions imposed on capital accumulation and labor, a smaller boost to the economy and slightly lower multipliers.

To summarize, our main result is the fact that high levels of public debt in the steady state produce lower multipliers when the public spending shock hits at the steady state but larger multipliers when the shock hits at the ZLB. The chief reason relies on the combination of two features of our economy: $(i)$ the fact that fiscal policy becomes self-financing at the ZLB, therefore implying a fall in public debt and then a fall in distortionary taxes, while the opposite occurs in normal times; and $(i i)$ the fact that the rollover cost of debt and the output costs of taxation are higher when debt and taxes are larger. When debt is initially high, taxes are initially high as well, and the responses of debt and taxes are larger after a spending shock: public debt and taxes increase more in the high debt economy when the shock hits at the steady state, and fall more when the shock hits at the ZLB. Our main result is robust to considering substitutable public and private goods, and therefore does not rely on an exotic assumption, even though we argue that complementarity is empirically more realistic. It is also insensitive to the type of tax used to ensure fiscal solvency in the long run, as long as the tax used is distortionary: all the

\footnotetext{
${ }^{10}$ Corsetti, Meier, and Müller (2012) show that this large value is necessary to guarantee the determinacy of the equilibrium.
} 
above results hold when considering tax rules separately. Finally, it holds true under various tax rule parameters and for a range of empirically realistic values for the labor supply elasticity.

\section{Optimized public spending rules in a crisis}

We now consider endogenous variations of public spending. Our goal is to assess the extent to which higher levels of debt imply different optimized responses of public spending to a crisis shock. On the one hand, public spending might be more effective in stimulating output and hence escape a crisis. On the other hand, too much public spending could become costly if fiscal policy becomes non-self-financing and thus provokes a rise in future distortionary taxes. Thus, what is the welfare-maximizing path of public spending? Do higher initial levels of debt imply larger or smaller changes in public spending? Or should this more effective tool be used less intensively? To anwser these questions, we abstract from spending shocks per se and consider that the government follows a simple spending rule. The rule makes government spending react directly to the initial capital quality shock with some persistence:

$$
g_{t}-g=\rho_{g}^{*}\left(g_{t-1}-g\right)-d_{g}^{*} \varepsilon_{\xi, t}
$$

The coefficients $\left(\rho_{g}^{*}, d_{g}^{*}\right)$ are chosen to maximize the Hicksian consumption equivalent $\epsilon$ that solves:

$$
\left.E_{t}\left\{\sum_{s=t}^{\infty}\left(\beta^{s-t}\right) u\left(c_{s}, g_{s}, \ell_{s}\right)-\sum_{s=t}^{\infty}\left(\beta^{s-t}\right) u(c(1+\epsilon / 100)), g, \ell\right)\right\}=0
$$

Variable $\epsilon$ is expected to be negative after a large economic downturn. It measures the steadystate percentage of consumption loss associated with experiencing macroeconomic fluctuations, induced in our case by a negative capital quality shock. As seen in Appendix B, the shock implies an important drop in private consumption, inducing large current-period utility losses.

Figure 2 reports the optimized dynamic response of government spending after a 5 percent negative capital quality shock, as well as the net effects of this spending policy on macroeconomic aggregates. The latter are computed as the difference between the responses with an optimized policy and the responses with constant public spending.

First, Figure 2 shows that the optimized response of the government is to increase government spending under all configurations. Intuitively, raising public spending provides direct utility gains, since public expenditure enter the utility function of households. It also provides indirect utility gains as raising public spending at the ZLB produces a crowding-in effect of private consumption, and lowers the private investment crowding-out effect with respect to what happens during normal times. This result holds irrespective of the Edgeworth complementarity parameter 
Figure 2: Optimized response of government spending after a 5\% negative capital quality shock and net effect on macroeconomic aggregates.

\section{$c_{t}$ and $g_{t}$ complements $(\nu=0.45)$}
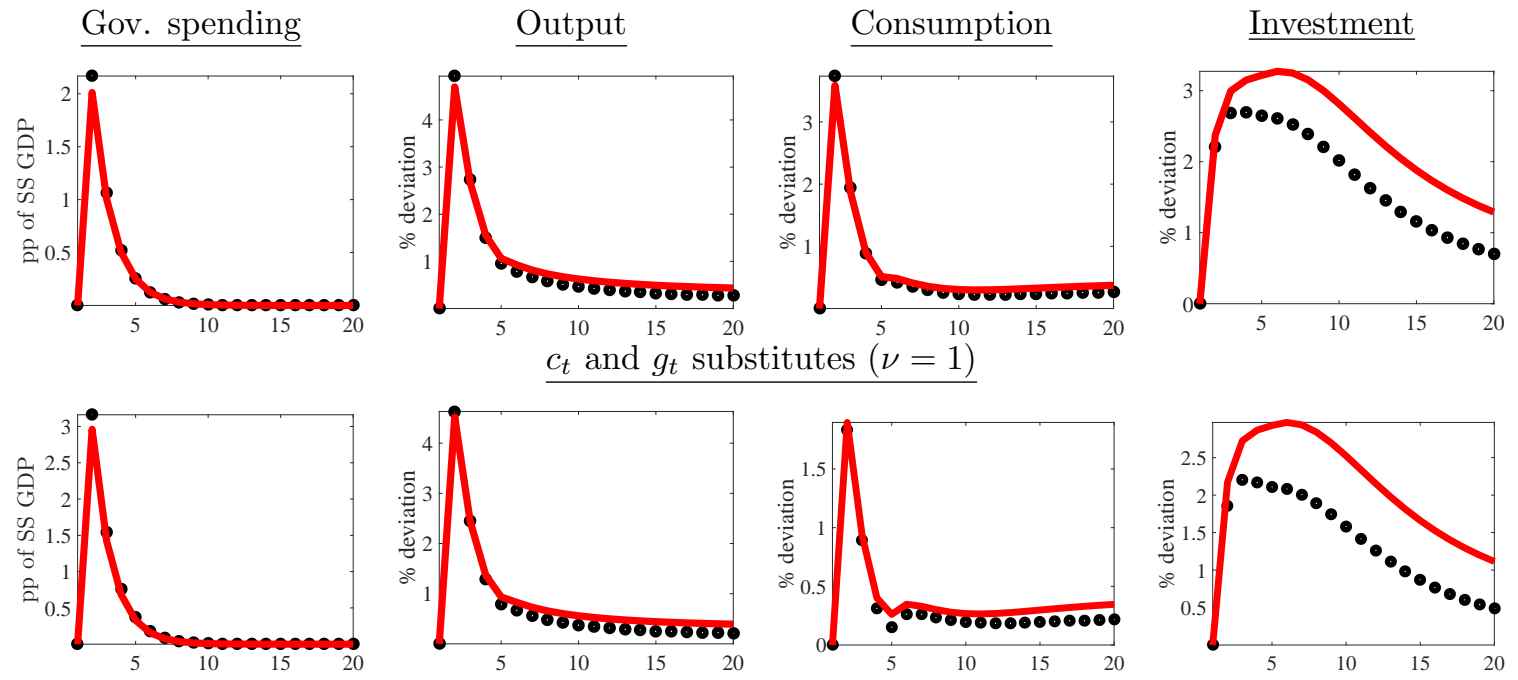

Black circles: $b^{g} /(4 y)=0.6$. Red: $b^{g} /(4 y)=1.15$.

$\nu$. As such, raising public spending raises the welfare of households. ${ }^{11}$

Second, the size of the government intervention is affected by the initial debt-to-GDP ratios, and by the Edgeworth complementarity parameter $\nu$. We shown in the previous sections that government spending policies are more effective (in the sense of a larger output multiplier) at the ZLB when the initial debt-to-GDP ratio is high. Figure 2 confirms this, as the optimized response of public spending is slightly smaller in this case, but produces comparable or larger positive effects on output, consumption and investment. This holds true whether public and private goods are complements or substitutes. In the latter case, public spending rise less, around 2 pp of steady-state GDP, while the increase is quite larger, around $3 \mathrm{pp}$ of GDP, when public and private goods are substitutes.

Table 3: Optimized policy rules.

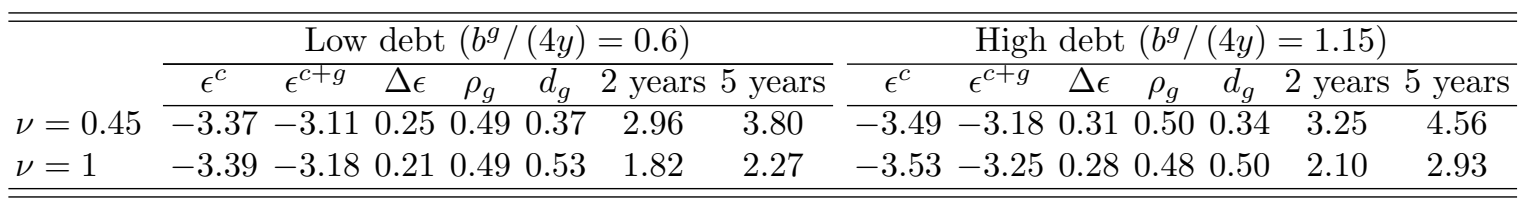

Note: $\epsilon^{c}$ denotes the welfare loss from the crisis with constant public spending, in percents of permanent consumption. $\epsilon^{c+g}$ denotes the welfare loss from the crisis with an active optimized spending rule. $\Delta \epsilon$ is the welfare gain from active spending policies: $\Delta \epsilon=\epsilon^{c+g}-\epsilon^{c} . \rho_{g}$ and $d_{g}$ are the optimized coefficients of the spending rule. Columns "2 years" and "5 years" respectively denote the present-value multipliers of output at the horizon of 8 quarters and 20 quarters.

\footnotetext{
${ }^{11}$ Our results, although derived in a different environment, are qualitatively and quantitatively consistent with those reported by Bilbiie, Monacelli, and Perotti (2018) and Nakata (2017).
} 
In addition, Table 3 confirms the results given by the IRFs: high initial levels of debt and complementarity between public and private goods are associated with less aggressive spending policies, given that the latter are more effective at stabilizing output. Indeed, output multipliers are larger at the horizon of 4 or 20 quarters when debt levels are initially high or when public and private goods are complements in utility. ${ }^{12}$

Closest to the above analysis are Bilbiie, Monacelli, and Perotti (2018) and Nakata (2017), who derive Ramsey policies subject to ZLB episodes. Some of our results are in perfect accordance with theirs. In particular, the fact that government interventions imply an increase in public spending. Further, the size of government interventions are broadly comparable, as well as the size of welfare gains from active policies at the ZLB. Our results differ however along crucial dimensions. First, Bilbiie, Monacelli, and Perotti (2018) assume lump-sum taxation. As such, the initial level of debt is irrelevant to the analysis. Second, Nakata (2017) finds that higher initial levels of debt should imply more aggressive spending policies while we find the opposite. In our view, this is due to the fact that the labor income tax follows a systematic feedback rule while this variable is an optimized policy instrument in Nakata (2017). In any case the design of optimal policies is not the main focus of our paper. We simply derive optimized rules to contrast the potential impact of the initial level of debt on the design of government interventions at the ZLB, and show that it potentially has non-trivial consequences.

\section{Conclusion}

This paper investigates the relation between the initial level of debt and the effectiveness of public spending shocks in a New-Keynesian model with capital accumulation, distortionary taxes and a lower bound constraint on the nominal interest rate. We find that countries with high debt are more fragile in the event of a crisis, as they experience larger economic downturns. In line with the literature, we also find that the spending multipliers are lower with a high initial debt-to-GDP ratio during normal times, and larger than during normal times when the ZLB is binding.

The novel result of the paper is that economies with a high initial debt-to-GDP ratio feature larger spending multipliers at the ZLB. The result is driven by the fact that fiscal policy becomes self-financing at the ZLB, allowing the debt-to-GDP ratio to fall after a spending shock, then producing a fall in distortionary taxes. Because the efficiency costs of taxation are convex, the subsequent fall in tax rates are larger when debt is initially higher, leading to larger positive effects on output. This raises the spending multipliers. Finally, this result implies that optimized spending policies at the ZLB are affected by the initial level of debt: a lower increase in public

\footnotetext{
${ }^{12}$ Notice that the values of output multipliers differ quite substantially from those reported in the first sections of the paper. These differences are attributed to the fact that the persistence and size of increases in public spending both depend on the rule, and are no longer determined exogenously. Given this, one should not seek to compare directly the values reported in Table 3 with those reported in Table 2.
} 
spending is required with high initial levels of public debt, as fiscal policy is more effective at stimulating output and provides larger reductions in the welfare losses from the crisis that pushed the economy at the ZLB. 


\section{References}

Adjemian, Stéphane, Houtan Bastani, Michel Juillard, Frédéric Karamé, Ferhat Mihoubi, George Perendia, Johannes Pfeifer, Marco Ratto, and Sébastien Villemot. 2011. "Dynare: Reference Manual, Version 4." Dynare Working Paper 1, CEPREMAP.

Auerbach, Alan J. and Yuriy Gorodnichenko. 2012. "Fiscal Multipliers in Recession and Expansion." In Fiscal Policy after the Financial Crisis, NBER Chapters. National Bureau of Economic Research, Inc, 63-98.

Auray, Stéphane and Aurélien Eyquem. 2017. "Episodes of War and Peace in an Estimated Open Economy Model." Working paper, GATE L-SE.

Bilbiie, Florin O., Tommaso Monacelli, and Roberto Perotti. 2018. "Is Government Spending at the Zero Lower Bound Desirable?" American Economic Journal: Macroeconomics :Forthcoming.

Boitani, Andrea and Salvatore Perdichizzi. 2018. "Public Expenditure Multipliers in Recessions. Evidence from the Eurozone." DISCE - Working Papers del Dipartimento di Economia e Finanza def068, Università Cattolica del Sacro Cuore, Dipartimenti e Istituti di Scienze Economiche (DISCE).

Bouakez, Hafedh and Nooman Rebei. 2007. "Why Does Private Consumption Rise after a Government Spending Shock?" Canadian Journal of Economics 40 (3):954-979.

Christiano, Lawrence, Martin Eichenbaum, and Sergio Rebelo. 2011. "When Is the Government Spending Multiplier Large?" Journal of Political Economy 119 (1):78-121.

Corsetti, Giancarlo, Keith Kuester, André Meier, and Gernot J. Müller. 2013. "Sovereign Risk, Fiscal Policy, and Macroeconomic Stability." Economic Journal 123:F99-F132.

Corsetti, Giancarlo, André Meier, and Gernot J. Müller. 2012. "What Determines Government Spending Multipliers?" Economic Policy 72:521-564.

Eggertsson, Gauti B. 2011. "What Fiscal Policy is Effective at Zero Interest Rates?" In NBER Macroeconomics Annual 2010, Volume 25, NBER Chapters. National Bureau of Economic Research, Inc, 59-112.

Erceg, Christopher and Jesper Lindé. 2014. "Is There a Fiscal Free Lunch in a Liquidity Trap?" Journal of the European Economic Association 12 (1):73-107.

Galí, Jordi, J. David López-Salido, and Javier Vallés. 2007. "Understanding the Effects of Government Spending on Consumption." Journal of the European Economic Association 5 (1):227270 . 
Gertler, Mark and Peter Karadi. 2011. "A Model of Unconventional Monetary Policy." Journal of Monetary Economics 58 (1):17-34.

Ilzetzki, Ethan, Enrique G. Mendoza, and Carlos A. Végh. 2013. "How Big (Small?) are Fiscal Multipliers?" Journal of Monetary Economics 60 (2):239-254.

Juillard, Michel. 1996. "Dynare : A Program for the Resolution and Simulation of Dynamic Models with Forward Variables through the Use of a Relaxation Algorithm." CEPREMAP Working Paper 9602, CEPREMAP.

Leeper, Eric M. 1991. "Equilibria under 'Active' and 'Passive' Monetary and Fiscal Policies." Journal of Monetary Economics 27 (1):129-147.

Leeper, Eric M., Nora Traum, and Todd B. Walker. 2015. "Clearing Up the Fiscal Multiplier Morass: Prior and Posterior Analysis." NBER Working Papers 21433, National Bureau of Economic Research, Inc.

McDaniel, Cara. 2007. "Average Tax Rates on Consumption, Investment, Labor and Capital in the OECD 1950-2003." Manuscript, Arizona State University 19602004.

Mendoza, Enrique G., Assaf Razin, and Linda L. Tesar. 1994. "Effective Tax Rates in Macroeconomics: Cross-country Estimates of Tax Rates on Factor Incomes and Consumption." Journal of Monetary Economics 34 (3):297-323.

Nakata, Taisuke. 2017. "Optimal Government Spending at the Zero Lower Bound: A NonRicardian Analysis." Review of Economic Dynamics 23:150-169.

Perotti, Roberto. 1999. "Fiscal Policy in Good Times and Bad." Quarterly Journal of Economics 114 (4):1399-1436.

Ramey, Valerie A. 2019. "Ten Years after the Financial Crisis: What Have We Learned from the Renaissance in Fiscal Research?" NBER Working Paper 25531.

Reinhart, Carmen M. and Kenneth S. Rogoff. 2011. "From Financial Crash to Debt Crisis." American Economic Review 101 (5):1676-1706. 


\section{A Debt-to-GDP and tax rates in the data}

We take a quick look at the relation between debt-to-GDP ratios and tax rates using various data sources. First, we take tax data from the dataset compiled by McDaniel (2007). Following the method of Mendoza, Razin, and Tesar (1994), she computes the consumption, labor income and capital income tax rates for 15 advanced countries from 1950 to 2014 . $^{13}$ We relate each of these tax rates with debt-to-GDP ratios taken from the updated Reinhart and Rogoff (2011) dataset for the same countries and the same time span in the following scatter plots.

Figure 3: Tax rates and debt-to-GDP for 15 OECD countries, 1950-2014

(a) Consumption tax rates

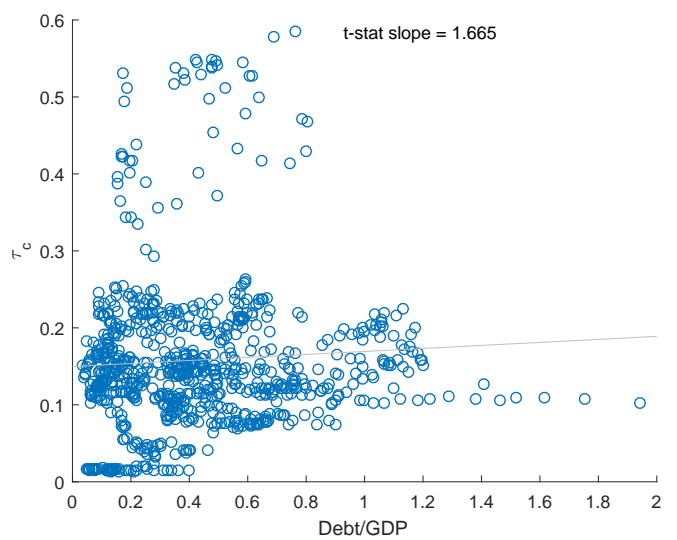

(b) Labor income tax rates

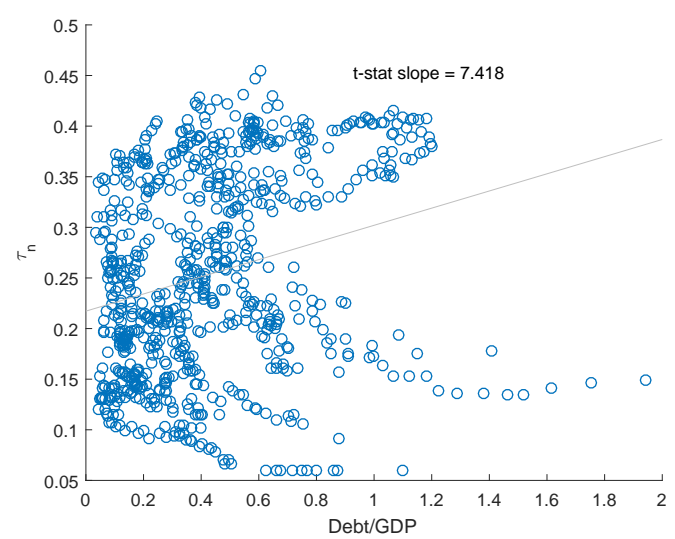

(c) Capital income tax rates

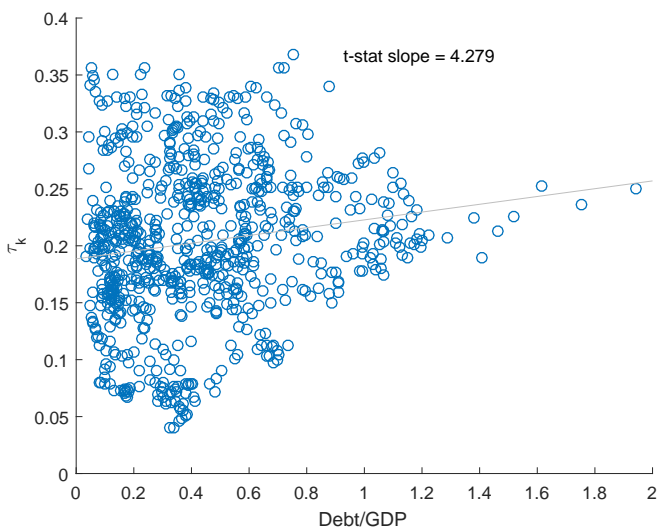

Notes: Tax rates are taken from the updated dataset of McDaniel (2007). Debt-to-GDP ratios are taken from the updated dataset of Reinhart and Rogoff (2011).

The above graphs are not a thorough empirical analysis but clearly suggest that higher levels of debt-to-debt are associated with larger tax rates on average over time. They are consistent with the idea of long-run fiscal sustainability. In addition, they suggest that labor income tax rates are more significantly and positively related to debt-to-GDP ratios. To confirm this first-pass analysis, we also plot various measures of labor income tax rates using OECD data. We take

\footnotetext{
${ }^{13}$ The following countries are considered: Australia, Austria, Belgium, Finland, France, Germany, Italy, Netherlands, Spain, Sweden, Switzerland, United Kingdom, United States.
} 
the OECD measures of total labor wedges at for different levels of wages $(67 \%, 100 \%, 133 \%$ and $167 \%$ of the average real wage) from the OECD Tax Database for 34 OECD countries between 2000 and 2016, and relate those labor income tax measures to the debt-to-GDP levels reported in the Central Government Debt OECD dataset for the same countries over the same period. ${ }^{14}$ Again, we pool all data together to get an idea of the average relation between debt-to-GDP and labor income tax rates. The second set of graphs confirms the positive relation between

Figure 4: Labor income tax rates and debt-to-GDP for 34 OECD countries, 2000-2016

(a) $67 \%$ of the average wage

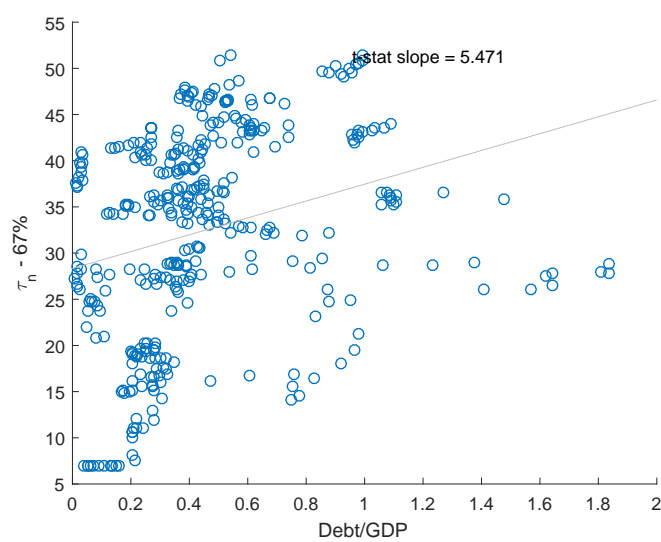

(c) $133 \%$ of the average wage

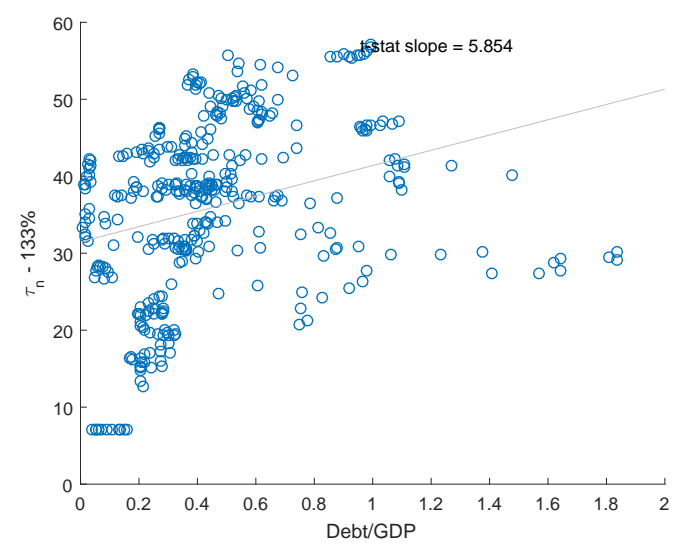

(b) $100 \%$ of the average wage

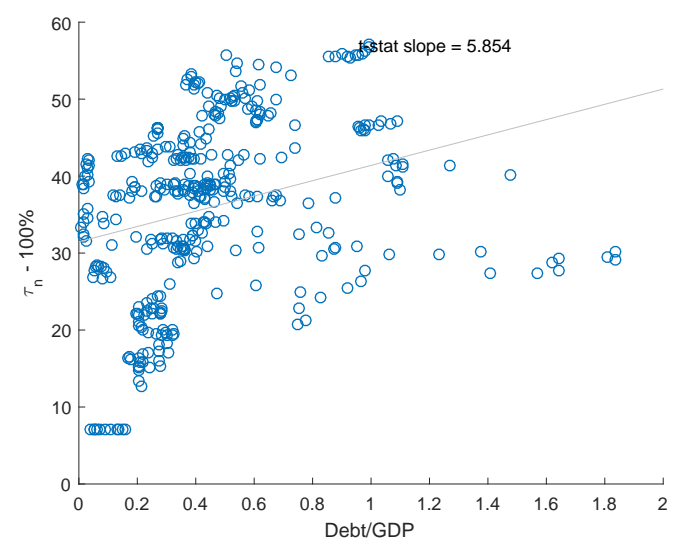

(d) $167 \%$ of the average wage

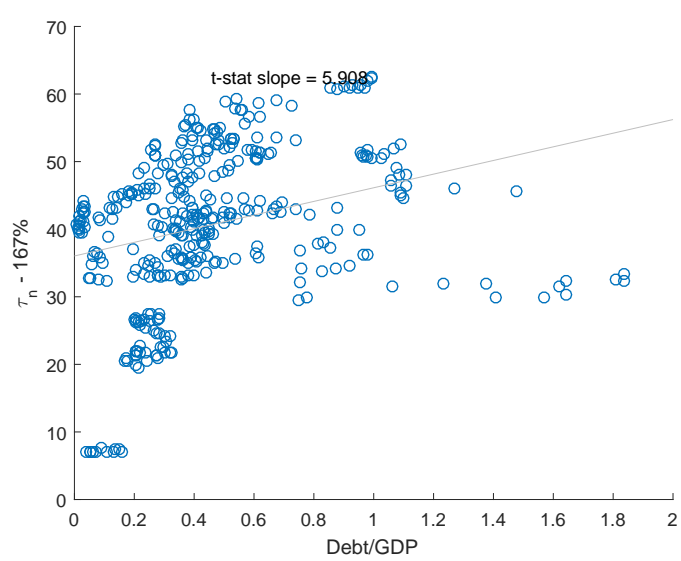

Note: Labor income tax rates are taken from the OECD tax database. They are computed using personal income taxes and social security contribution rates on gross labor income. Debt-to-GDP ratios are taken OECD Central Government Debt dataset.

debt-to-GDP ratios and labor income tax rates. Overall, this simple descriptive analysis shows that our assumption that consists in adjusting either the labor or the capital tax rate in the steady state when we vary the steady-state debt-to-GDP ratio is broadly consistent with the data.

\footnotetext{
${ }^{14}$ The following countries are considered: Australia, Austria, Belgium, Canada, Chile, Czech Republic, Denmark, Estonia, Finland, France, Germany, Greece, Hungary, Iceland, Ireland, Israel, Italy, Japan, Korea, Luxembourg, Mexico, Netherlands, New Zealand, Norway, Poland, Portugal, Slovak Republic, Slovenia, Spain, Sweden, Switzerland, Turkey, United Kingdom, United States.
} 


\section{B Additional figures}

Figure 5: IRFs to a $5 \%$ negative capital quality shock.

(a) Output

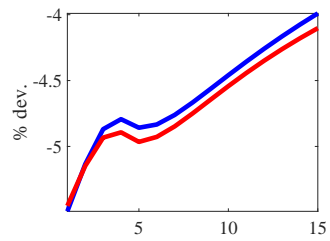

(e) Real wage

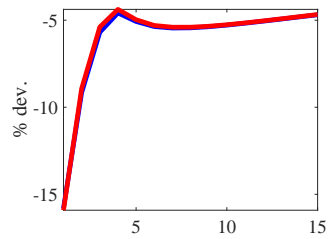

(i) Real int. rate

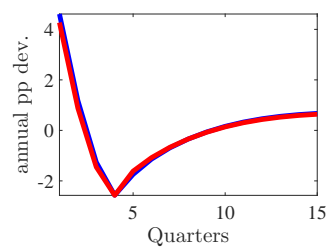

(b) Consumption

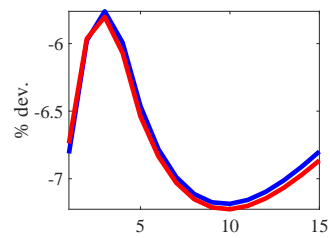

(f) Price of capital

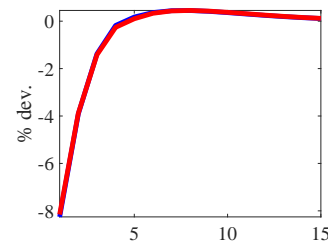

(j) Debt to GDP

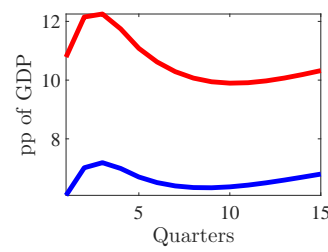

(c) Investment

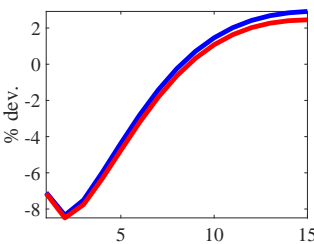

(g) Inflation rate

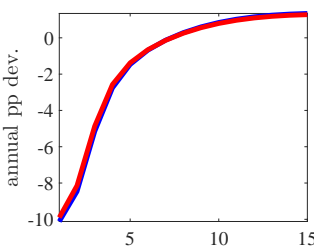

(k) Labor tax

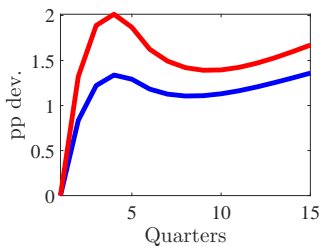

(d) Hours worked

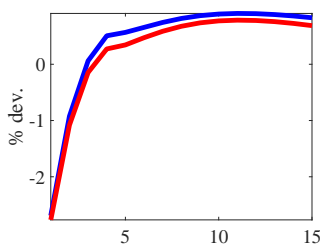

(h) Nominal int. rate

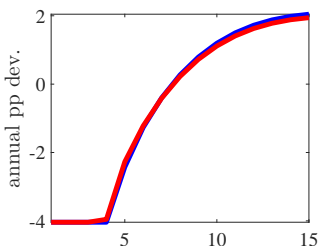

(l) Capital tax

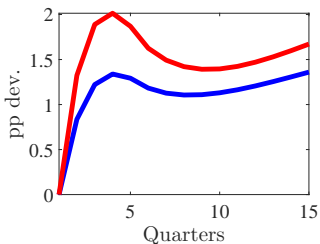

Black: $b^{g} /(4 y)=0.6$ and $\tau=0.2050$. Red: $b^{g} /(4 y)=1.15$ and $\tau=0.2481$. 
Figure 6: IRFs to a $1 \%$ public spending shock with a constant steady-state labor tax. At steady state.

(a) Output

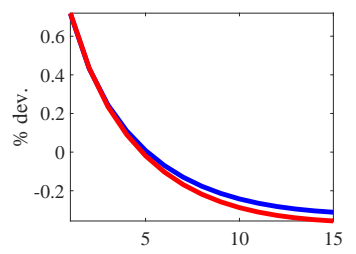

(e) Real wage

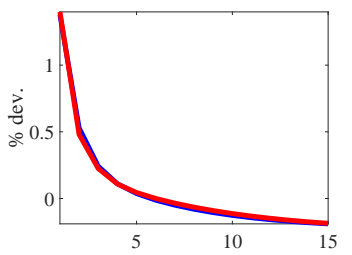

(i) Real int. rate

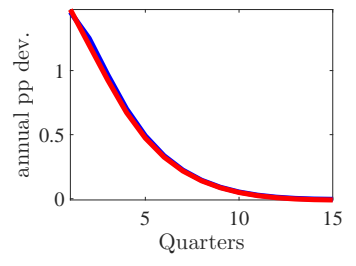

(m) Output

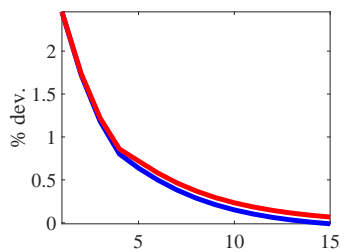

(q) Real wage

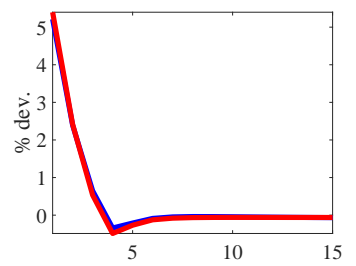

(u) Real int. rate

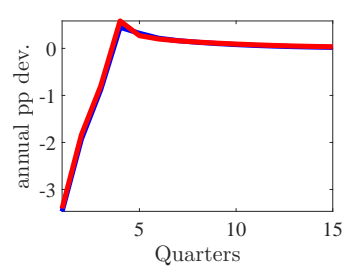

(b) Consumption

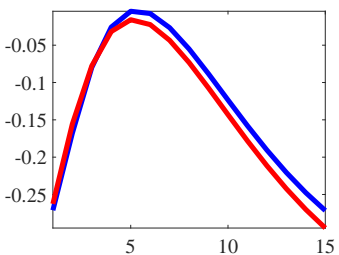

(f) Price of capital

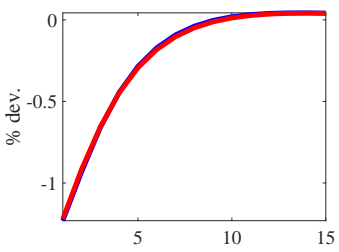

(j) Debt to GDP

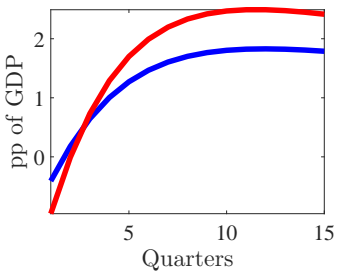

At ZLB

(n) Consumption

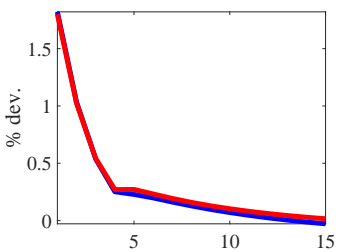

(r) Price of capital

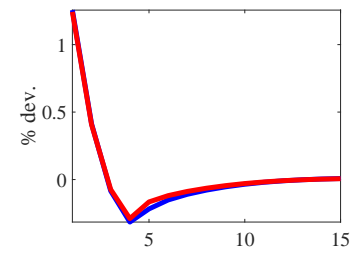

(v) Debt to GDP

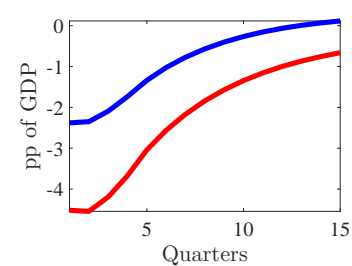

(c) Investment

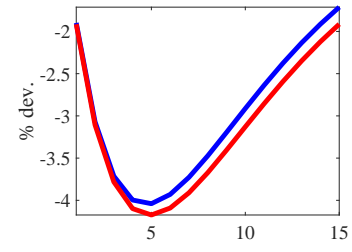

(g) Inflation rate

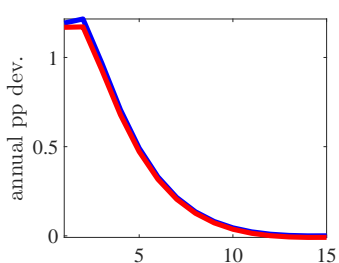

(k) Labor tax

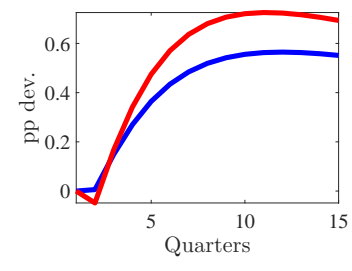

(o) Investment

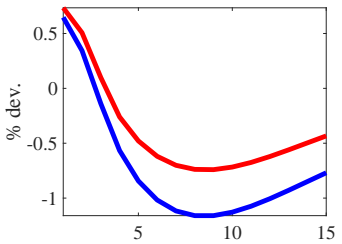

(s) Inflation rate

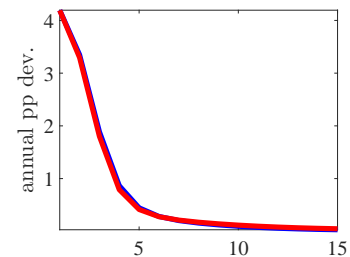

(w) Labor tax

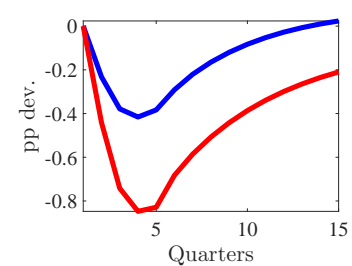

(d) Hours worked

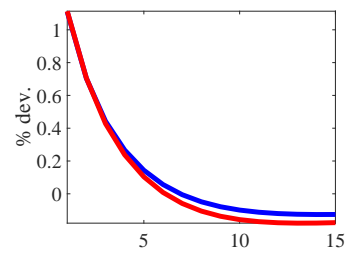

(h) Nominal int. rate

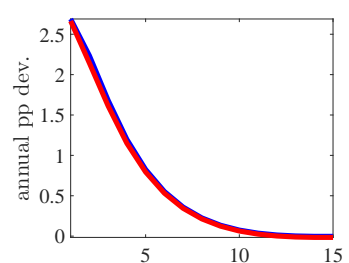

(l) Capital tax

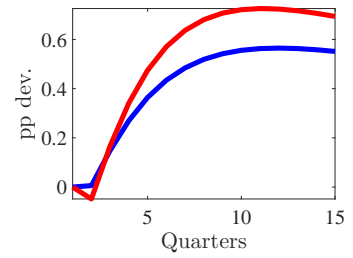

(p) Hours worked

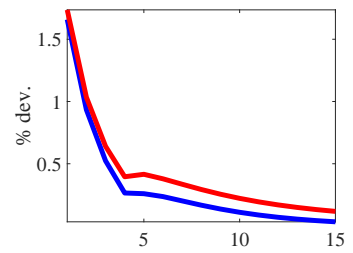

(t) Nominal int. rate

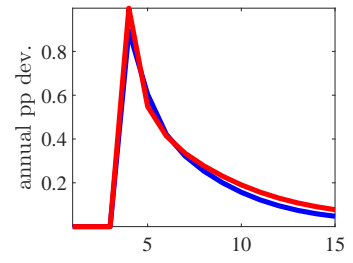

(x) Capital tax

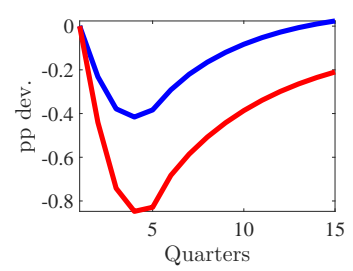

Black: $b^{g} /(4 y)=0.6$. Red: $b^{g} /(4 y)=1.15$. Varying steady-state levels of public debt are financed using a steadystate lump-sum tax or transfer instead of adjusting the steady-state labor income tax rate. The latter remains fixed at $\tau=0.2207$. 
Figure 7: IRFs to a $1 \%$ public spending shock with hand-to-mouth households at the steady state.

(a) Output

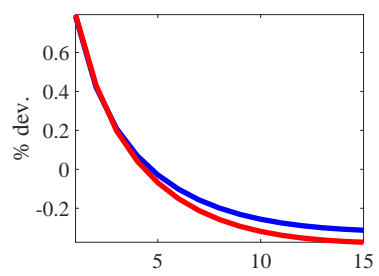

(e) Investment

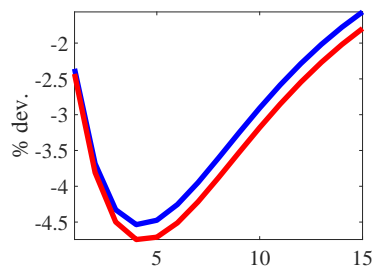

(i) Real wage

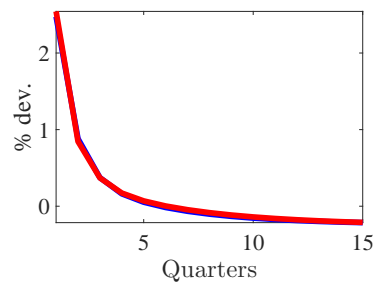

(m) Real int. rate

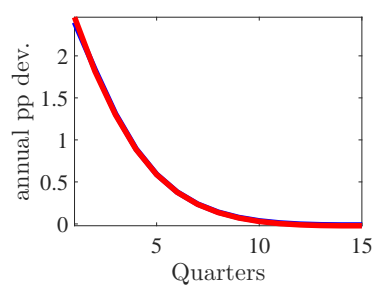

(b) Agg. cons.

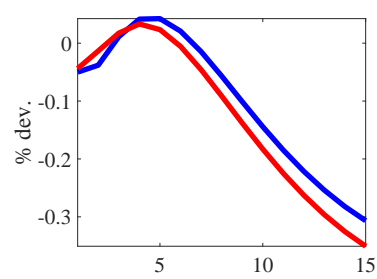

(f) Agg. hours

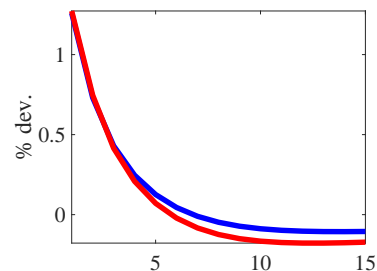

(j) Price of capital

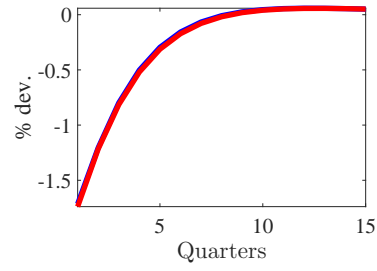

(n) Debt to GDP

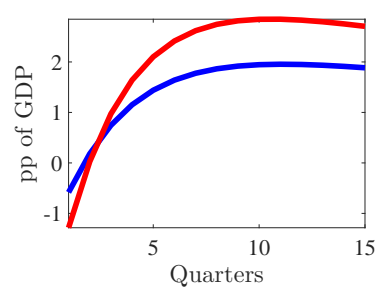

(c) $c_{t}^{o}$

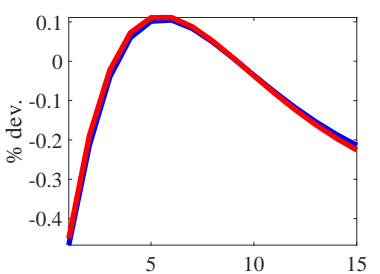

(g) $\ell_{t}^{o}$

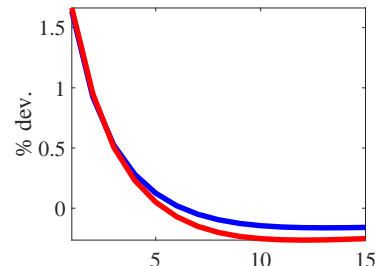

(k) Inflation rate

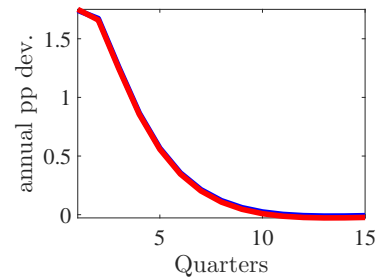

(o) Labor tax

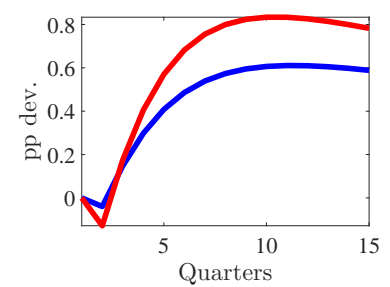

(d) $c_{t}^{r}$

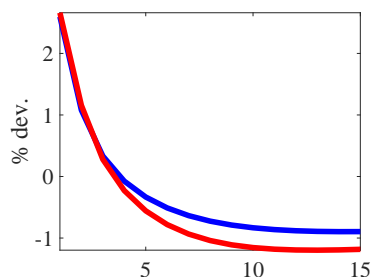

(h) $\ell_{t}^{r}$

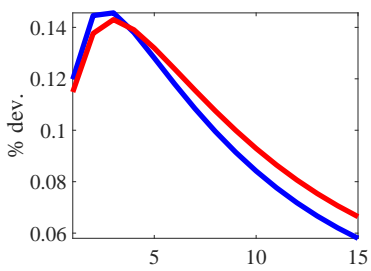

(l) Nominal int. rate

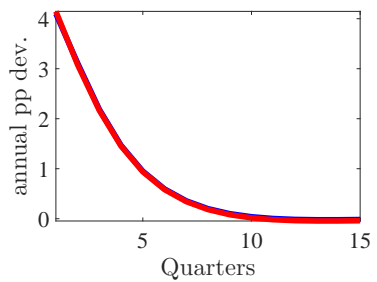

(p) Capital tax

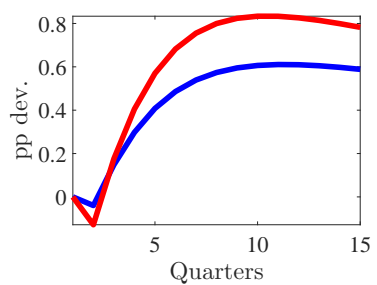

Black: $b^{g} /(4 y)=0.6$ and $\tau=0.2050$. Red: $b^{g} /(4 y)=1.15$ and $\tau=0.2481$. 
Figure 8: IRFs to a $1 \%$ public spending shock with hand-to-mouth households at the ZLB.

(a) Output

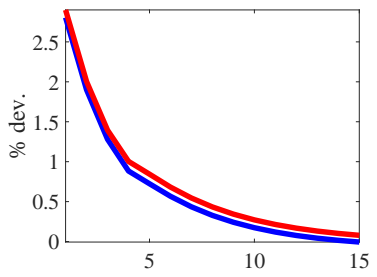

(e) Investment

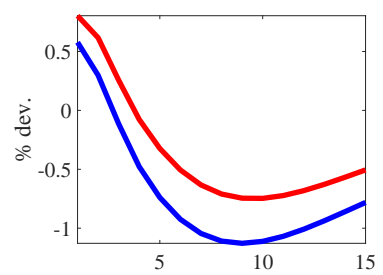

(i) Real wage

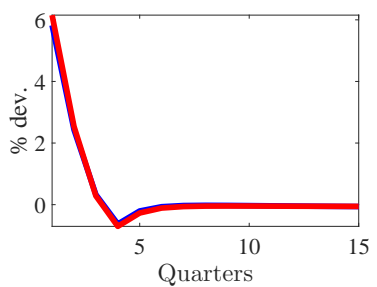

(m) Real int. rate

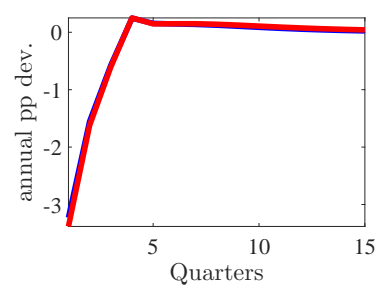

(b) Agg. cons.

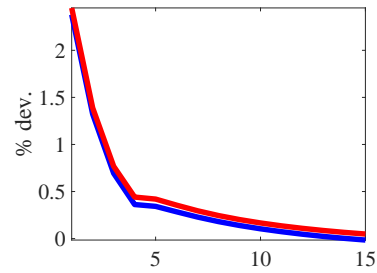

(f) Agg. hours

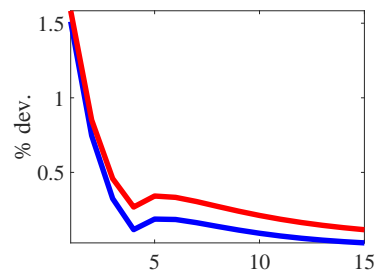

(j) Price of capital

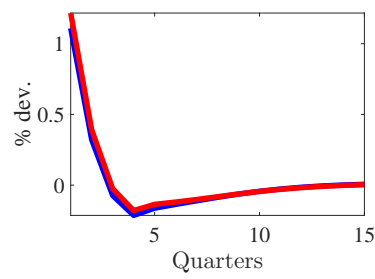

(n) Debt to GDP

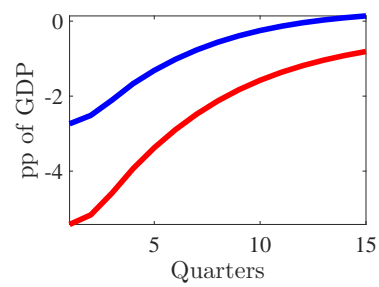

(c) $c_{t}^{o}$

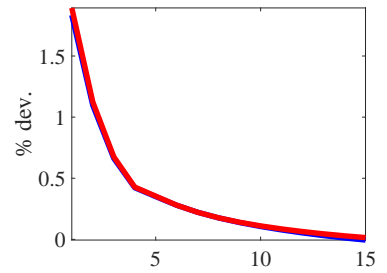

(g) $\ell_{t}^{o}$

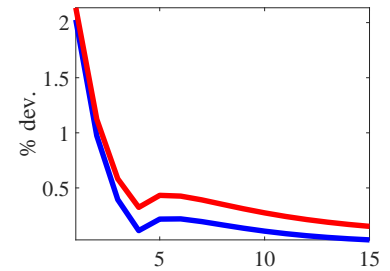

(k) Inflation rate

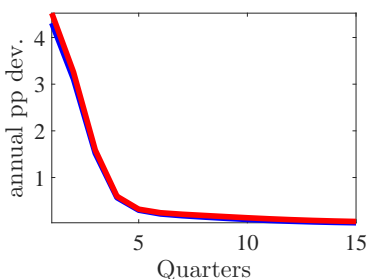

(o) Labor tax

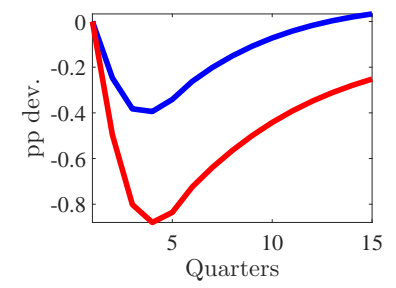

(d) $c_{t}^{r}$

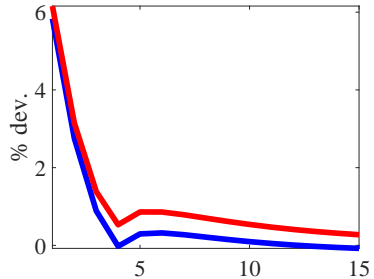

(h) $\ell_{t}^{r}$

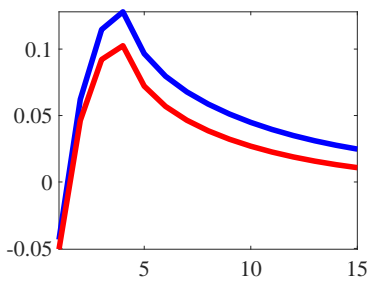

(l) Nominal int. rate

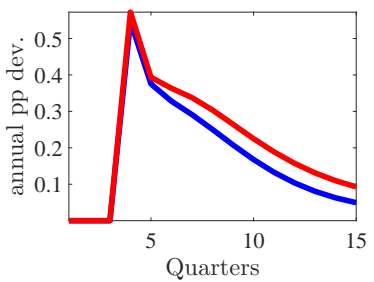

(p) Capital tax

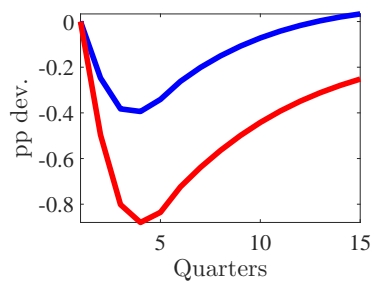

Black: $b^{g} /(4 y)=0.6$ and $\tau=0.2050$. Red: $b^{g} /(4 y)=1.15$ and $\tau=0.2481$. 